IMPACT OF THE INSTITUTIONAL FINANCIAL AID PROCESS ON STUDENTS OF COLOR

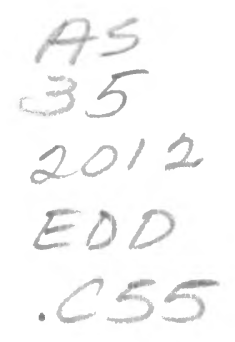

A dissertation submitted to the faculty of

San Francisco State University

In partial fulfillment of

The Requirements for

The Degree

Doctor of Education

In

Educational Leadership

by

Scott Charles Cline

San Francisco, California

August 2012 
Copyright by

Scott Charles Cline 2012 


\section{CERTIFICATION OF APPROVAL}

I certify that I have read The Impact of the Institutional Financial Aid Application Process on Students of Color by Scott Charles Cline, and that in my opinion this work meets the criteria for approving a dissertation submitted in partial fulfillment of the requirements for the degree: Doctor of Education in Educational Leadership at San Francisco State University.

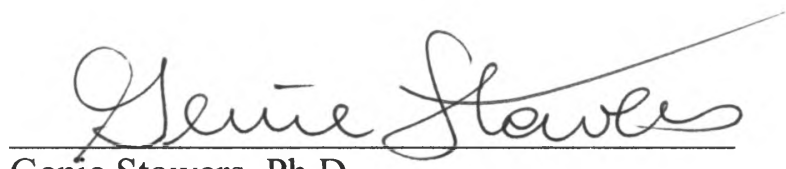

Genie Stowers, Ph.D.

Chair, Public Administration Program

San Francisco State University
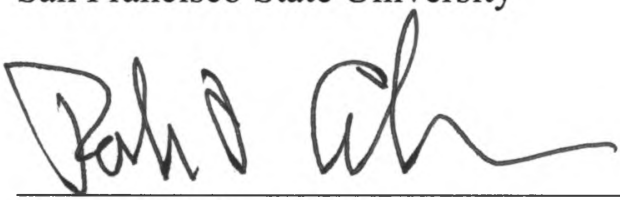

Robert Gabriner, Ed.D.

Director, Ed.D. Program

San Francisco State University

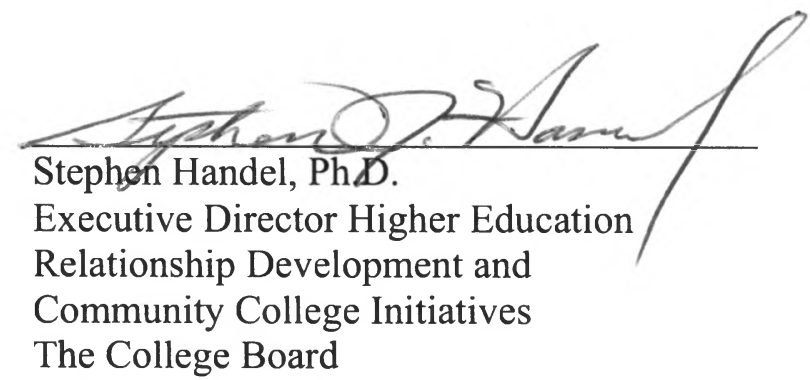




\title{
THE IMPACT OF THE INSTITUTIONAL FINANCIAL AID PROCESS ON STUDENTS OF COLOR
}

\author{
Scott Cline \\ San Francisco State University \\ 2012
}

The study examines the impact of the institutional financial aid process on students of color at the California Community Colleges. The institutional financial aid process starts after a student completes the Federal Free Application for Federal Student Aid and ends when a student has been awarded financial aid and makes a decision to enroll. Through the use of quantitativebased methods, two application failure rates were analyzed for African-American, Asian, Hispanic, and White students against the independent variables of the institutional application process using multiple-regression analysis. Calculated application failure rates for the 43 California Community Colleges in the study were as low as $2 \%$ and as high as $47 \%$. Findings include descriptive statistics of the current state of the institutional application process at the California Community Colleges as well as statistical analysis. The multiple-regression analysis found increases in application failure rates with significance with higher student to financial aid staff ratios for most student ethnicity groups and the overall student population. Analysis also found lowered application failure rates with significance with increased office hours and increased availability of financial aid forms online for most student ethnicity groups and the overall student population. Recommendations were made about how the California Community College financial aid offices might implement changes to decrease student financial aid application failure rates.

I certify that the Abstract is a correct representation of the content of this dissertation.

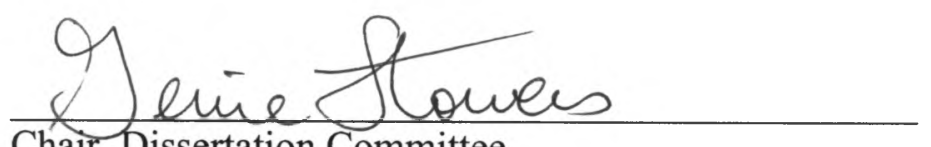

Chair, Dissertation Committee

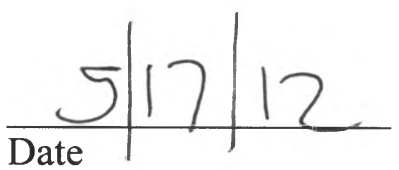




\section{ACKNOWLEDGEMENTS}

First, I would like to thank the support of Silvia Marquez, the Director of Financial Aid at California College of the Arts (CCA). She has always provided unquestioning support of my pursuit of this degree and this study. I am also extremely grateful to Dustin Smith in the CCA Financial Aid Office for his insights into the community college financial aid process.

This study would never have happened with out the patience, guidance, insight and calmness of my dissertation chair, Dr. Genie Stowers. Words cannot express how thankful I am to Dr. Stowers for taking my study on, pushing me when I needed it, and supporting the process. Also, I cannot thank enough my two committee members Drs. Robert Gabriner and Stephen Handel.

I wish to thank my parents, Jay and Yvette Cline, for their love and support. They have always been there to encourage me every step of the way in my education.

Last, but certainly not lest, I want to thank my wife, Erica Cline. Without her love and support I would never have been able to accomplish what I have achieved or this study. I will never be able to repay the debt I owe her. For this, and her love, I thank her. 


\section{TABLE OF CONTENTS}

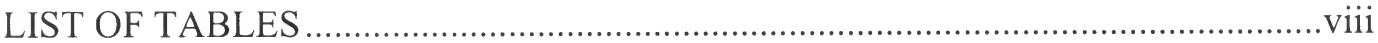

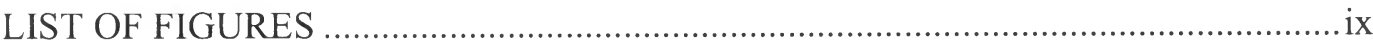

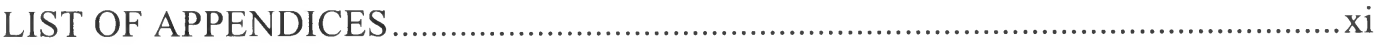

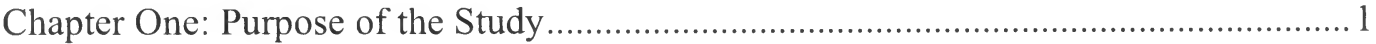

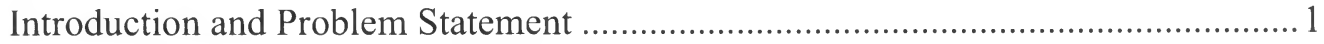

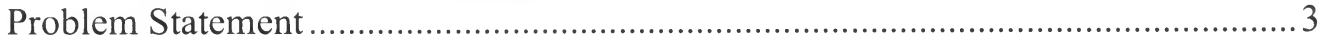

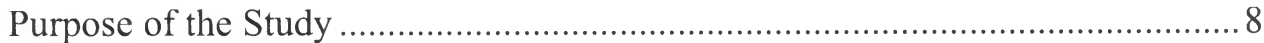

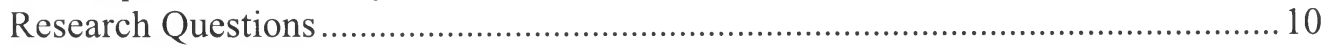

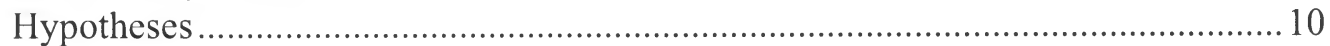

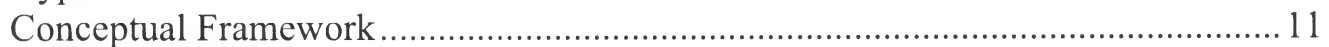

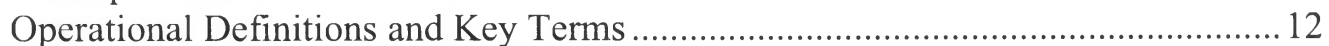

Statement of Delimitations and Scope of Study .................................................... 17

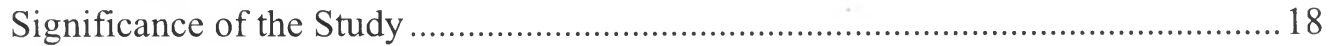

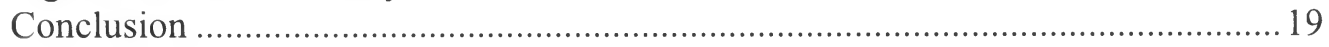

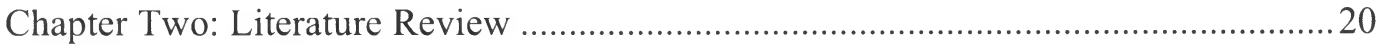

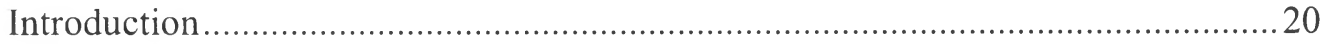

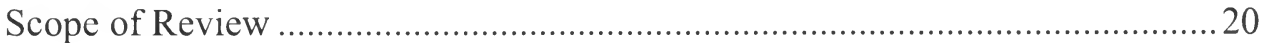

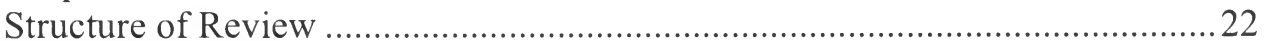

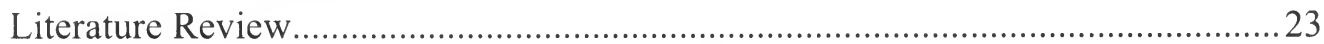

Working Theoretical Framework for Financial And Student Enrollment and

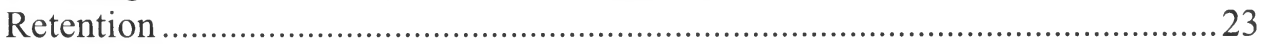

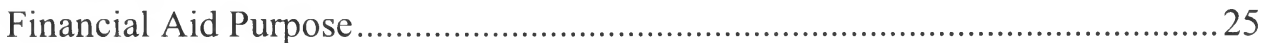

The Impact of Financial Aid and Student Retention .......................................28

Financial Aid and the California Community Colleges.....................................229

The Federal Financial Aid Process and Impact on Student Completion .............30

The Institutional Financial Aid Application Literature ...................................... 32

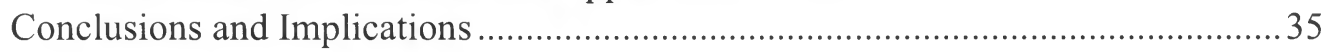

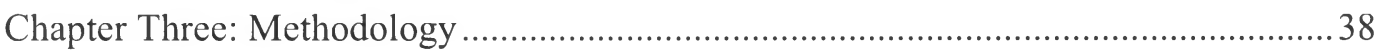

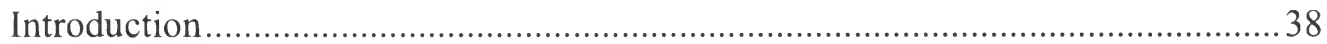

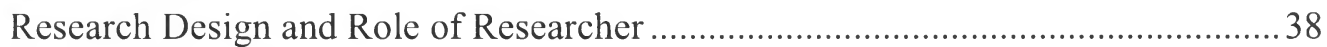

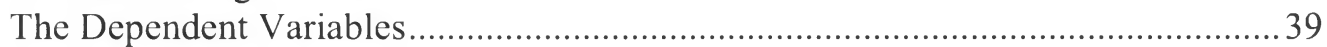

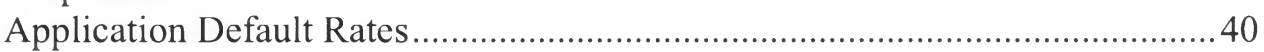

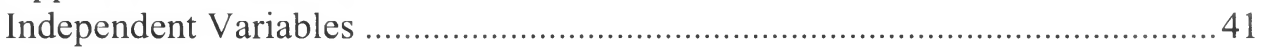




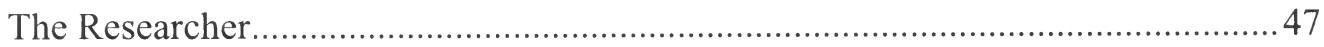

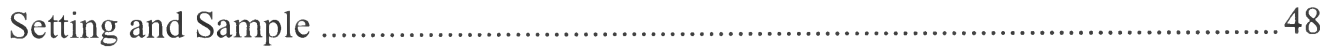

Ethics and Protection of Human Subjects.......................................................... 50

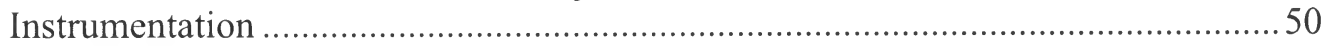

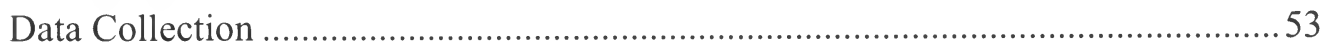

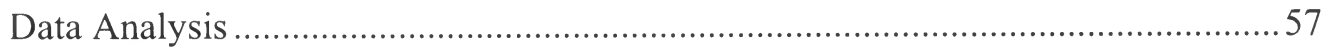

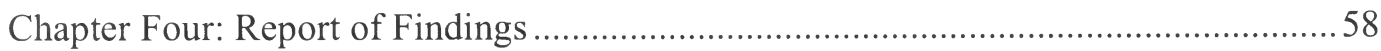

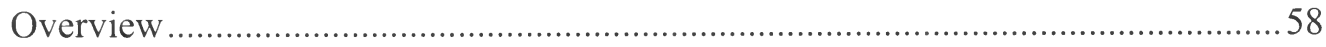

The Findings I - State of the Institutional Financial Aid Application.......................58

Institutional Application Failure Rates By Ethnicity-Calculation I ...........59

Institutional Application Failure Rates By Ethnicity-Calculation II..........6 64

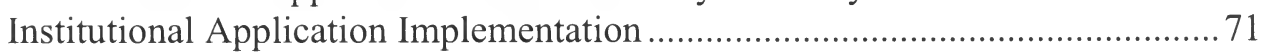

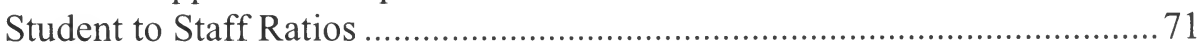

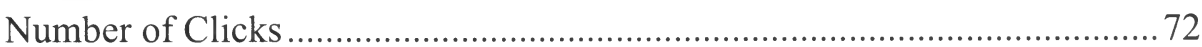

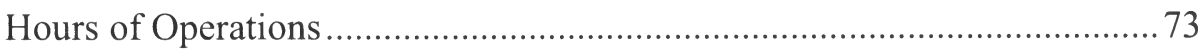

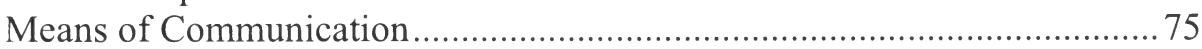

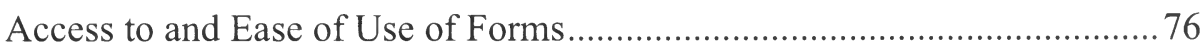

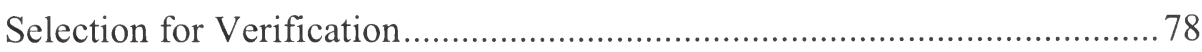

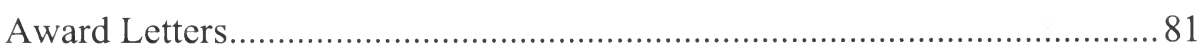

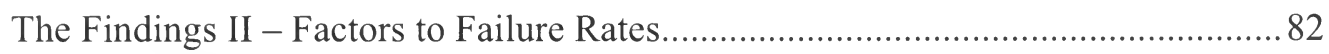

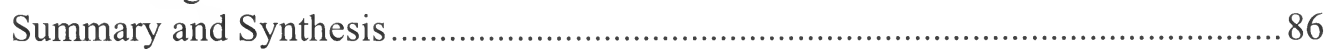

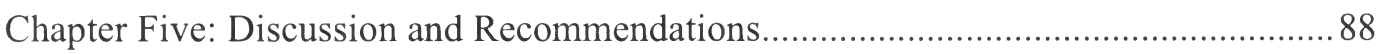

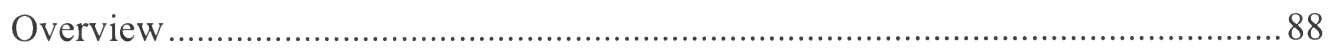

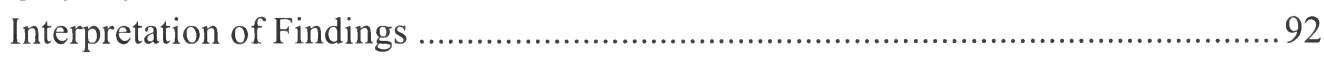

Financial Aid Students to Staff FTE Ratio .................................................... 93

Higher Total Office Hours ............................................................................... 94

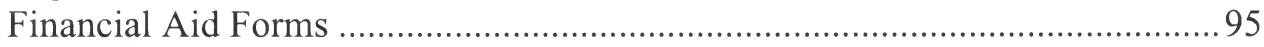

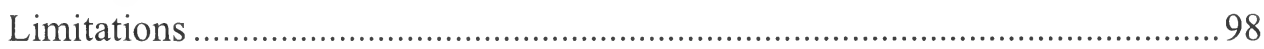

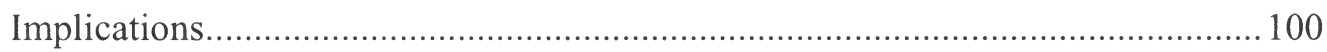

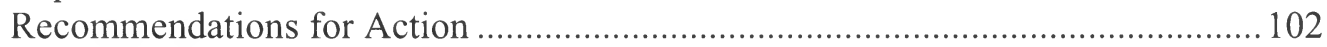

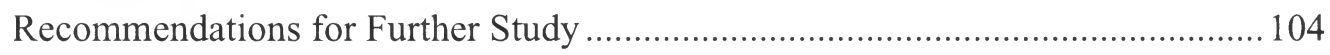

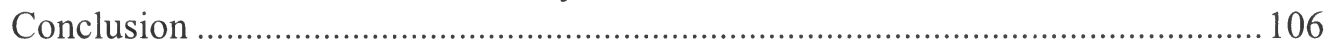

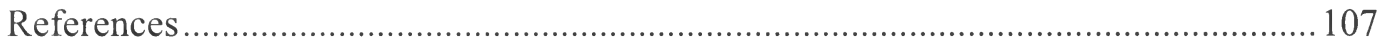

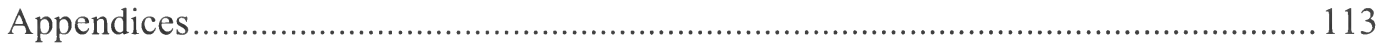




\section{LIST OF TABLES}

Table

Page

1. Overall Application Failure Rate II, Years. 7

2. Percentage of student loan borrowers by institutional type ....................................26

3. Comparison of data sample and all California Community Colleges.........................49

4. Descriptive statistics of institutions by weekly total of "normal" office hours. ..........73

5. Descriptive statistics of institutions by weekly total of "outside normal" office hours.

6. Institutional application failure rates that still enrolled by ethnicity and all students. 83

7. Institutional overall application failure rates by ethnicity and all students. 85

8. Summary Comparing Results Across Groups and Two Failure Rate Measures 90 


\section{LIST OF FIGURES}

Figure $\quad$ Page

1. The funnel of the financial aid process and the literature gap. .................................. 36

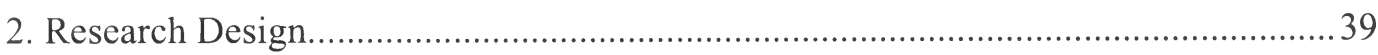

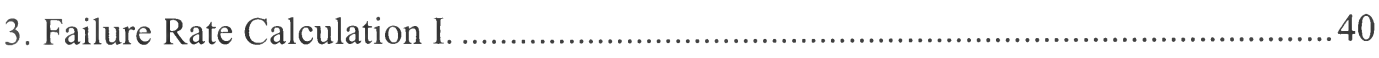

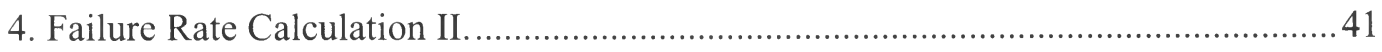

5. Example Financial Aid Application Critical Path ..................................................4 43

6. Example Financial Aid Application Feedback Loops. .............................................4 44

7. Count of institutions by percentage of students with Pell Grants..............................59

8. Count of institutions by application failure rate that enrolled for African-American

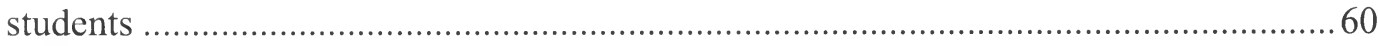

9. Count of institutions by application failure rate that enrolled for Asian students. .....61

10. Count of institutions by application failure rate that enrolled for Hispanic students.

11. Count of institutions by application failure rate that enrolled for White students.... 63

12. Count of institutions by application failure rate that enrolled for all students...........64

13. Count of institutions by overall application failure rate for African-American

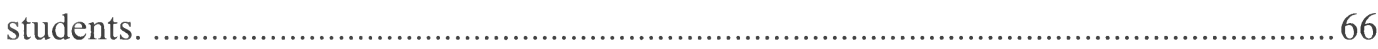

14. Count of institutions by overall application failure rate for Asian students. .............67

15. Count of institutions by overall application failure rate for Hispanic students. ....... 68 


\section{LIST OF FIGURES (CONTINUED)}

Figure $\quad$ Page

16. Count of institutions by overall application failure rate for White students.............69

17. Count of institutions by overall application failure rate for all students.................. 70

18. Count of institutions by ratio of financial aid students to financial aid staff FTE.... 72

19. Count of institutions by number of FAQs on the financial aid office website. ........76

20. Count of institutions by index of total financial aid forms on the financial aid office

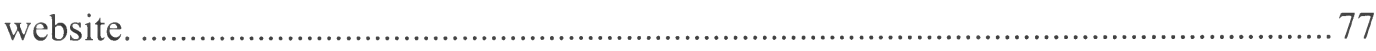

21. Count of institutions by how students are notified of being selected for verification.

22. Count of institutions by how students can submit verification documents. 80

23. Count of institutions by timeframe given to students in weeks to process application. 


\section{LIST OF APPENDICES}

$\begin{array}{lll}\text { Appendix } & \text { Page }\end{array}$

1. Financial Aid Institutional Process Collection Instrument ................................... 111

2. Quantitative Code Book .................................................................................. 120

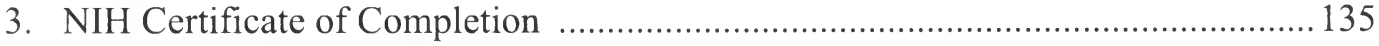

4. Human and Animal Protections Exemption Notice ............................................... 136 
Chapter One: Purpose of the Study

Introduction and Problem Statement

The 112 California Community Colleges (CCC) enrolls more then 2.9 million students annually (“Key Facts,” 2012). The 112 community colleges are organized into 72 loosely coupled districts that are overseen by a centralized Community College Chancellor's Office (“Key Facts,” 2012). The California Community Colleges are a low-cost open enrollment system that allows students to take courses with wide overall objectives, including job training, completion of an Associates Degree, transfer to a California State University, University of California or private college, or general community enrichment (California Community Colleges Chancellor's Office, 2011a). The California Community Colleges, both by design of the California Master Plan and the low-cost open-enrollment model, has multiple competing demands and missions to accomplish (California Community Colleges Chancellor's Office, 2011a).

The California Community Colleges have been, and continue to be, critiqued for failing to meet their multiple mission requirements (Hayward, Jones, McGuinness, Jr, \& Timar, 2004; Johnson \& Reed, 2007; Moore \& Shulock, 2010; Mortenson, 2009; Shulock \& Moore, 2007). The public critique on the California Community Colleges is not a new phenomenon (Hayward et al., 2004; Johnson \& Reed, 2007; Moore \& Shulock, 2006; Shulock \& Moore, 2007). The California Community Colleges have been required to meet multiple mission objectives that often pull the colleges in 
opposite directions (Moore \& Shulock, 2010). These criticisms occur in the context that the colleges often serve a more economically poorer student population than CSU, UC, or private non-profit colleges in California (The Institute for College Access \& Success, 2010a).

At the same time, substantial cuts have been made to the California Community Colleges over the past five years. California Community Colleges have had their overall budgets cut by 769 million dollars since 2009-2010 school year ("Key Facts," 2012). At the same time, while student fees have remained low compared to other states' community colleges, they have nearly doubled over the past 5 years ("Key Facts," 2012). In the 2006-2007 school year, per unit costs at a California Community College went from 20 dollars per unit to $\$ 46$ per unit starting with the 2012-2013 school year ("Key Facts," 2012).

Financial aid at the California Community College reduces the barrier to entry for students to enroll and achieve their educational goals (California Community Colleges Chancellor's Office, 2011b). This study examines the impact of the institutional financial aid application and application process on students' completion of that process. The financial aid process for most students starts with filling out the Free Application for Federal Student Aid (FAFSA) and ends with a student being awarded their eligible financial aid in order to enroll and attend their classes. This study uses a quantitative-based exploratory design to compare students' failure rates on the 
institutional financial aid application process to the implementation of the process by the California Community Colleges. The study presents both descriptive statistics of the current state of the California Community College institutional financial aid process and multiple-regression findings. The study discusses the implementations of both the descriptive statistics and the multiple regression findings. Finally, the study makes recommendations for the reducing student failure rates of the institutional financial aid progress.

\section{Problem Statement}

Financial aid is an important aspect that allows students to attend higher education in the United States. Even at the California Community Colleges, with the low cost of tuition, financial aid plays a vital role in making it possible for students to attend the colleges. The amount that students pay at the California Community Colleges to take courses is only a small portion of the cost a student incurs in order to make it possible for them to attend (The Institute for College Access \& Success, 2010a). The overall cost that a student incurs to attend a community college not only includes tuition, but living expenses, books and supply, personal expenses and transportation (The Institute for College Access \& Success, 2010a). The assumption that the community colleges tuition is very low often neglects these other substantial expenses. These expenses can easily be over $\$ 10,000$ a school year (The Institute for College Access \& Success, 2010a). These costs present a substantial barrier to entry for many 
students who do not have these costs covered or defrayed by other sources (The Institute for College Access \& Success, 2010a).

The purpose of financial aid is to reduce or eliminate this barrier to entry for students at the community colleges who want to enroll but cannot find other sources to cover or defray these costs (California Community Colleges Chancellor's Office, 2010). The financial aid system is complex. The financial aid system is made up of a complex interplay of federal, state and institutional sources (The Institute for College Access \& Success, 2007, The Institute for College Access \& Success, 2010b). With this interplay also comes a complex system of applications, checks, and balances that attempt to both reduce the barrier to entry for students and protect taxpayer and institutional funds. The student is left in the middle of a complex patchwork of funding sources, processes, and requirements. The complexity of the process is sizable. At the California Community Colleges, there are at least two different application processes including the federal application in the form (Free Application for Federal Student Aid [FAFSA]) and the state form (Board of Governors Fee Waiver Application), in addition to multiple institutional applications for institutional scholarships. Community college students have access to at least five different federal funding programs, including Federal Pell Grants, Supplemental Educational Opportunity Grants, Federal Work/Study funding, Federal Direct Subsidized and Unsubsidized Loans, and Federal Direct Parent PLUS loans ("Financial Aid General Info: Financial Aid Info," n.d.). Additional to federal 
funding sources, community college students in California have access to Board of Governors Fee Waivers, Cal Grants, and Chafee Grants ("Financial Aid General Info: Financial Aid Info," n.d.). All of these programs have specific eligibility requirements, enrollment requirements, maximum amounts and future requirements upon the student including repayment terms and conditions. The complexity within a financial aid system that intends to reduce the barrier to entry into the low-cost open enrollment California Community College stands in stark contrast to the intended goals.

The California Community College Chancellor's Office DataMart system contains data on how well the financial aid offices serve to mediate the financial aid system for students who seek to enroll in courses. During the 2009-2010 school year (the most recent completely audited data set), the 112 community colleges disbursed financial aid to just over one million students. Of the 112 community colleges, 51 of those colleges reported information to the DataMart on how many students started the financial aid application process (by completing the FAFSA), did not complete the institutional application process yet still enrolled in courses during the academic year. These 51 colleges represented just over half of the total students who were disbursed financial aid (at nearly 570,000 students). The overall rate for these 51 colleges of students who started the institutional application process by completing the FAFSA but did not complete the institutional process yet still enrolled is $8.8 \%$. In other words, for every 10 students who complete the FAFSA, nearly 1 of those students do not complete 
the process and yet still enroll without support from financial aid. This does not include students who did not complete the institutional application process despite completing the FAFSA, but who never enrolled at all. The DataMart data does indicate the reason a student did not complete the application process and did not enroll. It does not explain if the reason was due to student choice to go to another higher education institution or was due to the financial aid barrier. White students on average are the same as the overall average at $8.8 \%$. Hispanic students and Asian students tend to fair slightly better at $8.1 \%$ and $7.4 \%$, respectively, in not completing the application process, yet still enrolling in courses. Black students fare slightly worse at $10.4 \%$ not completing the application process, yet still enrolling in courses.

Overall, only slightly less than 1 in 10 students who do not complete the institutional process might not seem that large of an issue. Even the variance between the student racial groups might not seem that large of an issue. The problem becomes starker in the variance among institutions. Of the 51 schools, 19 schools had overall application failure rates higher than $8.8 \%$. One college had a failure rate of $56.3 \%$. While this one college was at the extreme, three colleges had failure rates above $20 \%$ and an additional 11 colleges had failure rates above $10 \%$. These groups represented nearly 37,000 students who successfully completed the FAFSA, yet failed to be able to navigate the institutional aspects of the financial aid process. Eliminating 13 of the smallest of the 51 California Community Colleges (based on financial aid recipients), 
there would still be less then the 37,000 students who were not able to complete the institutional application process, but nevertheless enrolled. These numbers are certainly underreported. These percentages do not include students who were disqualified for not making Satisfactory Academic Process (based on federal and institutional regulations) or students who started the financial aid process but never enrolled.

The number of students who fail to complete the institutional financial aid application process increases greatly when they include students who are disqualified for not making Satisfactory Academic Process and those who did not complete the financial aid process and never enrolled. Table 1 shows the overall percentage of students from the 51 colleges in the study who did complete the institutional financial aid process yet still enrolled, did not complete the institutional financial aid process and did not enroll and those students who did not complete because they were not making Satisfactory Academic Progress.

Table 1.

Overall Application Failure Rate II, Years.

\begin{tabular}{lccc}
\hline Student Ethnicity & Minimum & Maximum & Average \\
\hline & & & \\
African-American Students & 2.77 & 71.98 & 17.38 \\
Asian Students & 1.32 & 38.53 & 13.69 \\
Hispanic Students & 1.62 & 42.07 & 14.91 \\
White Students & 1.87 & 46.49 & 16.64 \\
All Students & 1.97 & 47.07 & 15.62
\end{tabular}

Source: Data developed from California Community College DataMart System. 
When these additional students are added into the numerator and the denominator, the failure rate nearly doubles. While the data from the DataMart system do not provide enough detail to determine exactly why these students did not complete the institutional financial aid application, these failure rates must be considered a potential problem. The program is even more a concern when all of these students already complete what most financial aid administrators and policy makers consider the hardest aspect of the entire financial aid process--completing the FAFSA (The Institute for College Access \& Success, 2010b).

Finally, the primary problem is that some colleges are able to assist students in completing the application process with a high percentage of success while other colleges are not able to accomplish the same objective. The primary focus of this study is the institutional implementation of the financial aid process and students successful completion of the process - what do some institutions do to assist students or help them through the process that other institutions do not do?

\section{Purpose of the Study}

The purpose of this study is to explore the relationship between the institutional implementation of the financial aid process and students' ability to complete the application process. This study examines why some colleges are able to assist students in completing the application process with a high percentage of success while other colleges are not able to accomplish the same objective. In an ideal world, all students 
who start the financial aid application process should be able to complete the financial aid process, be offered their eligible financial aid, and be able to enroll to attend and meet their education objectives. Short of the ideal world, a student should have the same chance of making it through the financial aid application process and enrolling in classes no matter what college they are trying to attend. A student should have the same access, information, and effective process of a financial aid office at one community college as at another community college. Whilé some of the community colleges in California are located in close proximity to each other, many students only have access to one or two of the colleges within their communities. At a minimum, equity for students requires that students have equal access and that access not be dependent on where a student lives.

This does not require all of the California Community Colleges financial aid processes and offices to be the same or that the financial aid processes should be centralized for all of the California Community Colleges. Often, different institutions and communities need different processes and different approaches. Differences in process and approaches are not antithetical to equity and are often required to achieve equity. Equity does demands similar outcomes. Similar outcomes do not currently exist in the failure rates of the California Community Colleges institutional financial aid application process. 
This study is important to both understand the current state of the institutional financial aid application process at the California Community Colleges and the aspects of that process that affects students' success and failure through that process. In an environment of diminishing budgets and cuts to programs and staff at the California Community Colleges, without knowing the critical parts of the financial aid application, administrators and policy makers are driving in the dark without headlights. This study examines this important aspect in today's environment and for the future.

\section{Research Questions}

The primary research question for this study is:

R1: How does the process of the community colleges' institutional financial aid application influence students' completion of the process?

Additionally, the sub-research question for the dissertation is:

R2: How does the process of the community colleges' institutional financial aid application influence African-American, Asian, Hispanic, and White students' completion of the process?

\section{Hypotheses}

The hypotheses for $\mathrm{R} 1$ are that aspects of process of the institutional financial aid application that increase available information about financial aid programs to students increase the amount of communication to students about their application status, increase the methods and amounts of contact for student to the financial aid office, and increase the simplification of the process result in higher completion rates of 
the process. The hypothesis for $\mathrm{R} 2$ is that different racial groups will be similarly affected by the aspects of the institutional financial aid process.

\section{Conceptual Framework}

The conceptual framework for this study assumes that 1) a deficit model should not be used to explain why certain students are not able to complete the financial aid process and receive financial aid; 2) college administrators and state and federal policy makers hold the responsibility for eliminating the financial barrier to entry for students who seek to go to college; and 3) rigorous testing of the effectiveness of the financial aid process is needed in order to make process and policy decisions (Apple, 2004; Davis, 1997; Hayward et al., 2004; Moore \& Shulock, 2006; Mortenson, 2009; Shulock $\&$ Moore, 2007). The deficient model has often been used to explain why certain students do not make it through the "system." This deficient model at times has been extended to understanding students' failure to complete the financial aid process. This study assumes that students do not complete the financial aid application process not due to the deficiencies themselves but instead due to the deficiencies of the institutional process (Davis, 1997).

The second part of the conceptual framework is tied closely with the first. College administrators and state and federal policy makers hold the responsibility for the financial aid application process. Often, institutional, state and federal regulations 
and policies are cited for not being able to change or improve processes. Student failure to complete the institutional financial aid process should signal issues with the process. Additionally, in the institutional application process, institutions have latitude in the implementation and continued student failure is either an implicit or explicit choice.

The last part of the study's conceptual framework is that decisions need to be based on rigorous testing in order to make improvements. Often, best practices are developed and implemented based on financial aid administrators' experience. This does not discount that experience. Instead the question must be asked more often, what outcomes are desired and then how can it be rigorously tested to achieve those outcomes.

Operational Definitions and Key Terms

Application Failure Rate I - The count of students who did not complete the financial aid application but still enrolled at the college divided by the sum of the students who received financial aid and the students who did not complete the process yet still enrolled.

Application Failure Rate II - The sum of students who never enrolled or attended, did not complete the process yet still enrolled, and those students disqualified due to lack of Satisfactory Academic Progress divided by the sum of those same students and the student who received financial aid. 
Board of Governors Fee Wavier - The Board of Governors (BOG) Fee Waiver is a program to allow low-income students to have their fees at the California Community College waived either by completing a BOG fee waiver application or by completing the FAFSA. Both applications require students and their families to provide certain financial information to determine qualifications. The separate application outside of the FAFSA allows students to get their fee waiver without completing all of the institutional financial aid process at many of the California Community Colleges.

Critical Path - The designated path of a financial aid office that students complete for the institutional aid application. This is the ideal process that students complete from the starting point to the ending point of the institutional aid application.

Expected Family Contribution - The expected family contribution (EFC) is determined by the FAFSA from a formula based on the financial and non-financial information that student and/or parents provided. It is used for determining a student's need and eligibility for all federal financial aid programs and most state and institutional financial aid programs.

Feedback Loops - The processes and designs of a financial aid office to return a student to the critical path of completing the institutional aid application. 
Free Application for Federal Student Aid - The Free Application for Federal Student Aid (FAFSA) is the general financial aid application required to be used by colleges and universities in order to determine federal financial aid eligibility. It is also used to determine eligibility for a number of state and institutional financial aid programs. Other types of application exist and some of them are used by the California Community College.

Institutional Application Process - The institutional application process starts at the point the college receives a student's FAFSA and ends when a student enrolls and receives their financial aid. The institutional application, either through design or happenstance, usually has a number of different steps that require a student to interact with the financial aid office.

Loan Default Rate - In order for a school to maintain eligibility to award federal financial aid grant and loan programs, the institution must keep their student loan defaults rates under certain percentages. The loan default rate is based on a cohort-year of students who enter repayment during a given federal fiscal year and then calculating how many of those students end up defaulting on their student loans within either twoor three-years after entering repayment. Currently, schools are held accountable for their two-year default rate, but starting in the 2013-14 school year, will be held accountable for three years after their students enter repayment. Relatively few 
community college students take out loans, but those students who do take out loans have traditionally had a much higher chance of defaulting on those loans (Cunningham \& Kienzl, 2011).

Pell Grant Program - The Pell Grant program is the primary federal grant program. It is also considered an entitlement program for students. Eligibility is based on a student's and/or parent's EFC from the FAFSA. If a student has an EFC that entitles them to a Federal Pell Grant that a college must award that grant to them. Since the low fees cost of the California Community College, most or all of any Pell Grant is refunded to the student for other educational or living expenses.

Satisfactory Academic Progress - Students who receive federal financial aid are required to maintain satisfactory academic progress (SAP) towards completing their program, degree or certificate. Colleges have flexibility in how SAP is calculated, including minimum GPA requirements, units completed to units attempted ratios, and maximum timeframes. Colleges also have flexibility in how financial aid eligibility warnings and appeals are handled when a student is found to not be making SAP.

Staffing Ratio - Staffing Ratio is defined as the ratio between students who received financial aid divided by the staff, faculty, and administrators assigned (based on FTE) to the financial aid office. This results in a ratio of $\mathrm{X}$ number of students per one financial aid office FTE. 
Student Loans - Student loans come from both the federal loan programs and private loan programs. Federal loan programs include loans that are taken out by the student and if the student is considered a dependent student, by their parents.

Additionally, private or "alternative" loans are provided by banks for students to take out for their educational expenses. Often, California Community College students are heavily discouraged by design and practice from taking loans while attending a community college. Colleges are held accountable for their student loan default rates after their students leave college. Community college students have traditionally had very high default rates, so colleges often discourage students from taking out loans in order not to jeopardize their ability to participate in the federal financial aid programs.

Verification - Verification is the process, required by the Department of Education, that a college takes to confirm the information that a student and their family provide on the FAFSA. Generally, the Department of Education selects $30 \%$ of all students who complete a FAFSA for verification by the institution. When a student is selected by the Department of Education, the school is required to confirm both financial and non-financial information. Often, in order to confirm this information, the school will request that the student and/or parent provide tax information and additional forms to confirm the FAFSA information before a student can receive financial aid. 
Often, schools will not provide a financial aid package to a student until the FAFSA information is confirmed.

\section{Statement of Delimitations and Scope of Study}

The scope of this study is the California Community Colleges and the institutional financial aid process that those colleges. Many factors affect a student's decision to enroll in a community college that may or may not be related to the financial aid process. Additionally, many factors affect a student's ability or desire to complete the financial aid application process and receive financial aid. The scope of this study is limited to the factors of the institutional financial aid application process that starts with a school receiving a student's FAFSA and ends with a financial aid award and enrollment.

The delimitation of this study is that it is limited in generalizability to the California Community Colleges. While the study may provide additional insight into the reason why the students at community colleges, or more generally higher education, may not complete the institutional financial aid application, the findings are limited to the California Community Colleges institutional financial aid application process and those factors that effect student success rates in completing that process. While the California Community Colleges have many similarities to other large community college systems and higher education institutions in other states in the United States, many of the aspects make the California Community Colleges unique. The uniqueness 
of the California Community Colleges compared to other community colleges and higher education institutions remains a limitation in generalizability.

\section{Significance of the Study}

The significance of the study is to develop an understanding of the institutional aid application impacts on how many students successfully complete the process and enroll. The study also develops understanding of the particular aspects of the institutional application process and the positive or negative impacts on the successful completion of the process. The study will help educational administrators and financial aid policy makers understand the impacts of policy and process decisions about how many students will successfully complete the institutional application process.

The study is also significant for student educational equity. The study shows how the institutional aid process impacts different student ethnic groups differently in the successful completion of the institutional aid process. Certain aspects of the implementation of the institutional aid process results in higher success rates for certain student ethnic groups while at the same time lowering success rates for other student ethnic groups.

The final significance of the study is the methodological advancement for the study of financial aid for financial aid administrators and financial aid policy makers. Few frameworks exist for analyzing the effectiveness of the institutional aid process. 
This study lays a framework that could be used for later adoption into the evaluation of effectiveness of institutional aid processes for future studies.

\section{Conclusion}

This study will examine the impact of the California Community Colleges institutional financial aid application on students' success and failure through that process. This study comes at a critical time of budget reductions and what those budget reductions mean student access and equity. Chapter 2 examines the literature about the financial aid process on which this study is based. Chapter 3 describes the methodology and the framework for the study. Chapter 4 presents the findings from the study through descriptive statistics of the current state of the institutional financial aid process at the colleges in the study and the findings from the multiple-regression analysis to answer the first and second research questions. Finally, Chapter 5 discusses the findings from Chapter 4 and develops the implications of those findings. Chapter 5 concludes with a discussion of further study that is still need understand the complex inter-workings of the financial aid process. 


\section{Chapter Two: Literature Review Introduction}

Much has been written about financial aid. This literature spans peer-reviewed empirical work to think tank white papers to political position papers to news and opinion pieces in the general media. The literature on financial aid spans the specialties of economics, political science, social policy, management, and ethics. During the past few years and even decades, financial aid has had a great deal written about it. Very little of the literature is not passionate and recommendations for both policy and practice abound.

This review examines the literature around the problem of students not completing the financial aid process and more specifically the literature on reasons that students do not complete the institutional application process. This review outlines what is already known in the literature about the financial aid application process and what remains to be examined.

Scope of Review

This literature review is not a review of the history of the financial aid system from post-World War II to the present day since that line of inquiry is not helpful to understanding the current financial aid system and the funding of the higher education system in the United States. (Kantrowitz, n.d.).

Instead, this literature review draws on two veins to explore what has been examined in the area of student completion of the financial aid process. The first vein 
was empirical research located in peer-reviewed and non-peer-reviewed journals and books. The search for these materials was through keyword searches on financial aid within a time span of 1985 to the present. The year 1985 was chosen since the current implementation of the financial aid programs and progress dates from the late $1980 \mathrm{~s}$ onward (Kantrowitz, n.d.). For example, the current Stafford Loan programs were created in 1987 and the FAFSA was created in 1992 (Higher Education Amendments of 1992, 1992; Kantrowitz, n.d.). Modern electronic process, dissemination of information, and applications in financial aid started to form by the late 1990s with FAFSA on the Web in 1997 and to come fully together in the early 2000s. Additionally, the literature published in 1985 begins this account because the literature at that time describes a financial aid context leading into the early 1990s that has a striking similarity to the current economic and budget climate of 2008 to 2012 (See St. John, 1992).

The second area for this review comes from the many think tanks and organizations that produce independent research, white papers, position papers and best practices recommendations. Some of these organizations have focused on the broad issues of college price and cost to the specifics of the California Community College financial aid and access. These types of sources were found through both reviewing the websites of the major known think tanks and organizations as well as a search of LexisNexis Academic for financial aid and policy related articles. The primary review of this these sources were from 2000 to the present. 
Finally, the last area of literature for this review was dissertations or theses completed between 2000 and present in ProQuest Dissertations \& Theses. This additional review was important since many of the working financial aid professionals who have completed a Masters or Doctoral Degree often do not end up publishing their work in academic journals. Much of the "collective" wisdom and knowledge of the financial aid profession is retained within these sources and conference presentations that often become inaccessible after a degree is completed or conference has ended. Nevertheless, a great deal of effort was expended to attempt to review and include this information.

\section{Structure of Review}

The structure of this review starts with a theoretical framework on financial aid and enrollment in college that was developed for working financial aid professionals. The theoretical framework focuses on both being a workable model as well as one that can be used by professionals in the field to inform both policy and practice. After establishing the theoretical framework, the review examines the research on the purpose and impact of financial and student enrollment and retention. Next the review moves to the literature on financial aid at the community colleges - in particular, the California Community Colleges.

After establishing the literature and the landscape for the impact financial aid has on student enrollment and retention, the review then addresses to student success 
through the application process. The first level of the application process is the federal financial aid application. Next the review moves to the second level of the institutional application process. Finally, the review examines the current knowledge on how the institutional application process affects students' ability to complete the process as well as the best practices that have been the predominant focus of the literature in this area to date. Ultimately, the review concludes with addressing the gap in the literature on how the institutional implementation of the financial aid application impacts student success in completing the process and enrolling.

\section{Literature Review}

Working Theoretical Framework for Financial And Student Enrollment and Retention

St. John (1992) introduced a working framework for understanding why students enroll and stay in school that is considered the intersection of social and economic characteristics. Earlier theories explaining why students decide to enroll or not enroll in college were based solely on college pricing (Davis, 1997). These studies were critiqued for not taking into account many other factors, including students' backgrounds and educational goals, which might influence students' decision to enroll or retain (Davis, 1997). St. John (1992) built on these previous theories and combined social considerations of students with economic considerations into a workable framework that could be used by college administrators to measure impact and influence decision making. The theory and design of the framework was developed to 
guide institutions in evaluating their financial aid effectiveness but has since been tested using large national data sets (St. John, 1992).

The theory holds that student enrollment and retention decisions are based on three factors (St. John, 1992). The first factor is a student's previous academic performance and demographic profile. The second factor is the students' current experiences in college. Finally, the last factor is financial aid and college costs. All three factors can influence a student's decision to enroll and stay in college. A critique of the theory might be that the first and second factors use a deficit model to help explain why a student might not enroll or stay. While reading the theory at face value, this might be the case, but further exploration and examination suggests that these first two factors are not designed to be causal, only correlational. This is supported with St. John's focus on making this a workable framework that could be used by institutions to inform practice (Davis, 1997). The primarily focus of the theory is on the institution and not the students.

The focus on informing practice also means that financial factors include the process that students need to complete in order to receive financial aid. Without financial aid, students are only shown costs and not assistance. St. John's work and the studies that followed based on his theory primarily used data on students who received financial aid (Chen, 2008; Stephen L DesJardins \& McCall, 2010; Lassila, 2011). Due to the previous focus on students who received financial aid, it is important to further 
explore the impact of the institutional aid application process. The institutional aid application process might limit student access to financial aid in the first place and influence student decisions to enroll and stay in school. The theory and workable framework becomes the theoretical basis for this study to examine the impact of the institutional financial aid process on students completing the application process.

\section{Financial Aid Purpose}

Financial aid has the stated purpose of reducing the economic barrier to entry for students who would not otherwise be able to afford to attend an institution of higher education (Long \& Riley, 2007). Financial aid comes from a combination of federal, state, and institutional funding. Most institutions state that financial aid is to be delivered in an equitable and fair way to students who wish to enrollment at a college or university (Stepehn L DesJardins, Ahlberg, \& McCall, 2006). Financial aid is usually a combination of funding that does not need to be repaid by a student (called grants, scholarships, fee waivers, stipends) and funding that does need to be repaid by a student and/or parents (usually called loans) (College Board, 2011). The first source of funding can generally be referred to as gift-aid. The second source of funding is often called financing or deferred payments and more generally, loans. The largest portion of financial aid for community college students is in the form of gift-aid funding (College Board, 2011, The Institute for College Access \& Success, 2007). Few community college students, compared to four-year college and university students, use financial 
aid that needs to be repaid (loans) (The Institute for College Access \& Success, 2010a). Table 2 shows the percentage of students by institution type who take out student loans. Table 2

Percentage of student loan borrowers by institutional type.

Percentage of Students
Borrowing Loans

$\begin{array}{lc}\text { Two-Year Public } & 37.2 \% \\ \text { Two-Year Private (for-profit) } & 97.6 \% \\ \text { Four-Year Public } & 61.1 \% \\ \text { Four-Year Private (non-profit) } & 70.6 \% \\ \text { Four-Year Private (for-profit) } & 97.0 \%\end{array}$

Source the 2007-2008 National Postsecondary Student Aid Study compiled by finaid.org (http://www.finaid.org/loans/)

Another way to think about the types and purpose of financial aid in the context of reducing the barrier to entry is that gift aid directly reduces either the direct or the indirect cost of attending a college (The Institute for College Access \& Success, 2010a). The second source of funding, loans, reduces the barrier to entry for either direct or the indirect costs, but only defers that barrier to entry to another or extended time period (The Institute for College Access \& Success, 2010a). 
Both the direct and the indirect costs of attending a college create the barriers to entry for attending colleges are (College Board, 2011, The Institute for College Access \& Success, 2007). Direct costs come in the form of costs that a student must pay a college in order to attend. The most common examples of direct costs include tuition and fees (The Institute for College Access \& Success, 2007). Sometimes direct costs can include books and supplies provided by the school but requiring payment, housing and food, and health insurance. Indirect costs include all of the items that a student needs to pay for but which are not paid to the college. Examples of indirect costs include books and supplies, housing and food, transportation, health insurance, and general personal expenses (The Institute for College Access \& Success, 2007). These direct and indirect costs can easily be over $\$ 10,000$ for a California Community College student (California Community Colleges Chancellor's Office, $2011 \mathrm{a}$, College Board, 2011).

The purpose of financial aid is to allow students who cannot afford to pay $\$ 10,000$ a year to still afford to attend college. The goal of the financial aid process is to evaluate students (and their families) ability to meet these costs through the different combination of financial aid programs (California Community Colleges Chancellor's Office, 2010). Since financial aid at the California Community Colleges comes primarily from taxpayer dollars, the process has the additional responsibility to both protect public funds and to distribute the funds equitably (California Community 
Colleges Chancellor's Office, 2010, California Community Colleges Chancellor's Office, 2011a). Due to these dueling mandates to both protect taxpayer dollars and provide access to students, the role of financial aid can be viewed often as mutually exclusive endeavors.

The Impact of Financial Aid and Student Retention

A number of studies have examined the link between receiving financial aid and student retention. Some studies have focused on student retention as a measure of success and others have focused on graduation and transfer as the critical metric. Generally, the literature has found positive impacts on both student retention and student success from the receipt of financial aid as well as and the subsequent lower net costs (Baum, McPherson, \& Steele, 2008). Studies have shown that low-income students do not retain or graduate at the same rates as high-income students (Lassila, 2011). Receiving financial aid, especially in the form of grants for all economic levels of students, has shown positive impacts on enrollment, retention, and graduation (Baum et al., 2008; Long \& Riley, 2007; Novak \& McKinney, 2011).

The body of research on the impact of financial aid shows strong positive correlations to student enrollment, retention and graduation. The next point of focus in the literature is how financial aid influences student decisions and success at relatively low-cost institutions, like community colleges, and particularly the California Community Colleges. 
Financial Aid and the California Community Colleges

The large-scale studies of the impact of financial aid and student retention and success have extended to the community colleges. Much of the financial aid that students receive at community colleges come in the form of grants or gift-aid (California Community Colleges Chancellor's Office, 2011b, College Board, 2011; Mendoza, Mendez, \& Malcolm, 2009). The sources of these funds are primarily either federal or state funds (California Community Colleges Chancellor's Office, 2010, California Community Colleges Chancellor's Office, 2011a, College Board, 2011, The Institute for College Access \& Success, 2010a). Only a small portion of students, 68,000 students in the 2008-09 school year out of 892,000 students who received aid that year, at the California Community Colleges take out loans through the federal loan programs (California Community Colleges Chancellor's Office, 2010, California Community Colleges Chancellor's Office, 2011a).

However, a recent study has shown that, of those community college students who do take out loans, they have some of the highest default rates in the country, compared to their peers in public and private four-year college and university students (Cunningham \& Kienzl, 2011). Due to this and the increase in the institutional default rates that colleges are held accountable for, many of the California Community College financial aid offices actively discourage student loan borrowing (The Institute for College Access \& Success, 2007). Often the discouragement of community college 
students getting student loans leaves students with gaps between their grant financial aid and their cost of attendance (The Institute for College Access \& Success, 2007). This can lead to more students not enrolling full-time or having to work more hours in order to fill the gap (The Institute for College Access \& Success, 2007).

While the research shows that students at the California Community Colleges might not be fully utilizing the financial aid resources that are available to them, students who receive financial aid, particularly grant aid, at community colleges do have increased instances of enrollment, retention and graduating or transfer compared to students who do not receive financial aid (MacCallum, 2008). The question then becomes how do students apply and receive financial aid.

The Federal Financial Aid Process and Impact on Student Completion

The starting point for most students is the Department of Education and the Free Application for Federal Student Aid ("FAFSA - Free Application for Federal Student Aid," n.d.). Over the past two school years, the FAFSA has undergone a number of revisions with the goal of reducing the burden on students and families to complete the application (Baker, Bergeron, \& Madzelan, 2011; Kollock, Parkinson, \& Baker, 2011). The Department of Education has introduced a number of skip-logic and simplification processes in order to reduce the number of questions many students and their families need to answer to submit a FAFSA (Kollock et al., 2011). They have also introduced direct connections that allow many students and families to pull their financial 
information from their tax return into the FAFSA directly from the Internal Revenue Service (Kollock et al., 2011). These updates have changed the interface between the students and the Department of Education. The Department of Education reported that these changes have reduced the average time it takes for a student to complete the FAFSA from 32 minutes in 2010-2011 school year to 23 minutes in 2011-2012 school year (Kollock et al., 2011). It is the belief that these changes will streamline the process a student completing the process at the federal level. Unfortunately, the changes to the FAFSA will not be ready to be evaluated for at least another full academic year cycle at the earliest.

Many of these changes to the FAFSA from the Department of Education have occurred in response to the research and literature about the large portion of students who never start a FAFSA or students who start the FAFSA and do not complete it to the point where it can be submitted to a college (Asher, 2007). A number of studies and reports have examined why students do not complete the FAFSA. Students often do not complete the FAFSA due to the belief that they will not be eligible for any financial aid (Kantrowitz, 2009a, 2009b; King, 2004, 2006; LaManque, 2009).

Other reasons why students report not completing the FAFSA is because the process is seen as too complicated or requires too many documents in order to complete (Asher, 2007; Kantrowitz, 2009a, 2009b; King, 2004, 2006). Studies have found that outreach and educational programs help to increase completion rates of the FAFSA 
(King, 2004, 2006; LaManque, 2009). Nevertheless, many students either never start the FAFSA or start the FAFSA but do not get to the point where it can be submitted to the colleges to start the institutional application process. Some studies have reported that the number of students who do not complete the FAFSA each year, who would otherwise be eligible, could be as high as 2.3 million students who would have received Federal Pell Grants (Kantrowitz, 2009b). The vast majority of these students who do not start or complete the FAFSA are lower-income students and their families (Asher, 2007; Kantrowitz, 2009a, 2009b; King, 2004, 2006; LaManque, 2009). Additionally, a large portion of students who do not complete a FAFSA are students who plan to attend a community college (King, 2004, 2006).

The financial aid process starts with a student completing the FAFSA, but it does not end with the FAFSA (Richardson, 2008). Next is an examination of literature on how financial aid offices implement the institutional application process.

\section{The Institutional Financial Aid Application Literature}

After a student completes the FAFSA, the student is then transferred to the institution that they are seeking to attend and receive financial aid from. The largest portion of the application process for the student occurs at this institutional level (The Institute for College Access \& Success, 2007). Three recent research studies have attempted to describe the impact of the institutional implementation of the financial aid process on student success at the California Community Colleges. The Institute for 
College Access and Success (TICAS) has produced two studies, "Green Lights \& Red Tap" (The Institute for College Access \& Success, 2007) and "After the FAFSA" (The Institute for College Access \& Success, 2010b) that explore the impact of the institutional application process on student success. The first report resulted in a number of findings and recommendation for best practices in the financial aid process that were found at the selected California Community Colleges with high student success rates, as measured by degree completion and transfer rates. The report, based on their findings, made recommendations on how to get information out to students, how to help students navigate the process, and how to disburse aid funds to students. The study's methodology used interviews and document review in order to draw findings based on those colleges with high transfer rates and degree completions. The study did not thoroughly examine the findings to see if any actually increased student completion of the financial aid process or ultimately, student retention or completion.

The second study from TICAS, "After the FAFSA," examined a subset of the financial aid application process called verification and made recommendations for best practices for colleges based on the impact of verification on students (The Institute for College Access \& Success, 2010b). Verification is the process by which the Department of Education requires an institution to review student's financial aid and household information to confirm accuracy of the FAFSA information ("Federal Student Aid Handbook," n.d.). The study found a large amount of work required by the institution 
and the student for little noticeable change in Pell Grant eligibility. While this research included findings on one part of the institutional application process, it only included data from 13 of the California Community Colleges that used the same financial aid software and only a portion of the overall institutional financial aid process.

Another study has also attempted similar types of analyses to connect financial aid operations and student success rates (MacCallum, 2008). MacCallum (2008) studied the connection between certain operations of the financial aid office and student success in terms of enrollment, transfer rates and degree completion at the California Community Colleges. The study used survey data from all of the California Community Colleges. The survey data was collected during the 2001-2002 school year and asked the financial aid offices to respond to questions about operational aspects of the office. Many of the survey questions asked about basics of the financial aid office, included title and background of the financial aid director.

Other questions on the survey asked about the perceptions of the financial aid office vis-à-vis other offices and departments in the financial aid office. The study found that the title of the head financial aid administrator had a positive impact on retention of students, but the head financial aid administrator having a background in business had a negative impact on student enrollment. The study reflects the operations of the California Community College financial aid offices nearly 10 years ago, and it did not model or evaluate the whole institutional financial aid application process. 
These three studies attempted to build portions of the pictures on how the institutional financial aid process impacts students' completion of the process and ultimately enrollment, retention, and completion. At the same time, all three of these recent studies recommended changes to the financial aid office and application process based on these partial views. What is missing in the literature is a model and an examination of the institutional financial aid process from the time a student completes the FAFSA that is transferred to the college to the point when a student enrolls.

\section{Conclusions and Implications}

A student who manages first to make the decision to attend a college, then manages to survive all the odds stacked against them to complete the FAFSA, only to get to the institutional process of the California Community Colleges and fail to complete the process is the focus of this study. The causes of this outcome for students have not yet been studied. The financial aid process from start to end is laid out like a funnel (see Figure 1). 
Gap in the Literature and Focus of Study

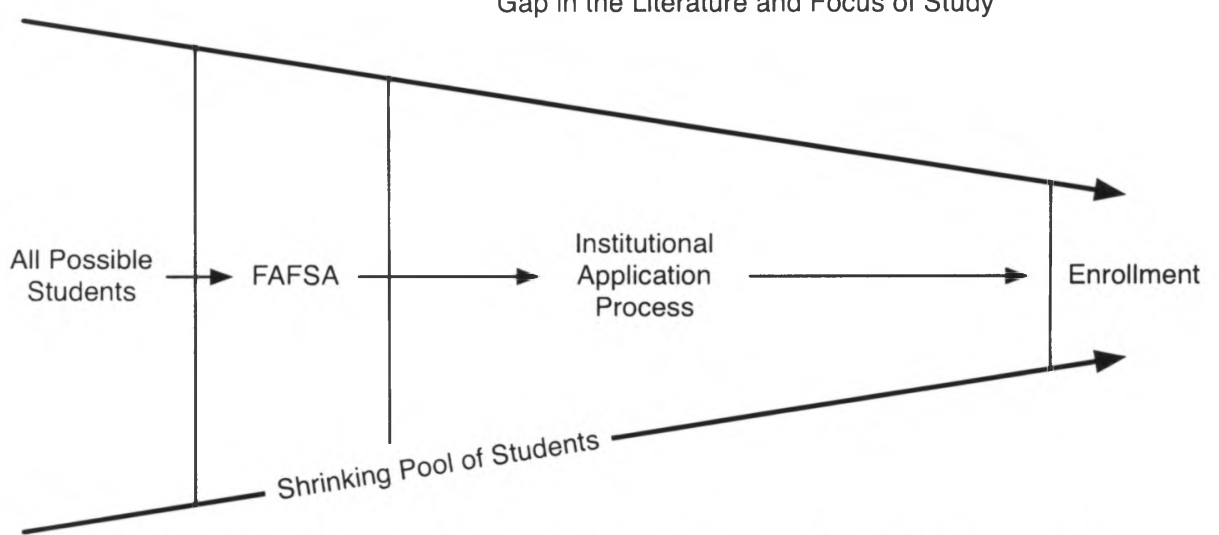

Figure 1. The funnel of the financial aid process and the literature gap.

With each step forward in the process, the pool of students left standing grows smaller and smaller. The part of this process that the literature has not examined is between when a student is transferred from the FAFSA to their college of choice and when they might successfully complete the institutional portion of the process to enroll.

Some studies have examined aspects of the financial aid process quantitatively using the California Community Colleges' retention and transfer as indicators of success. Other studies have reviewed portions of the institutional financial aid application process quantitatively and qualitatively in order to make recommendation of best practices to improve the process. No study has been conducted to examine the effectiveness of the entire institutional financial aid application process of getting students through the process and enrolled in the college. This study will examine the institutional financial aid application and evaluate it based on the ability of students to complete that process and enroll in the California Community Colleges. The next 
chapter will describe how the study was developed, how the institutional financial aid application process was operationalized and data collected for analysis to answer the gap in the literature. 


\section{Chapter Three: Methodology \\ Introduction}

This chapter outlines the methodology of the study. The chapter first discusses the research design and the role of the researcher in the study. It next moves to outline the setting and sample for the study in comparison the overall population. Measures used to maintain ethical standards and the protection of human subjects are established. The Financial Aid Audit instrument design is outlined and discussed how it was vetted for the study. Finally, the chapter concludes with the steps of data collection and analysis for the study.

The methodology used by the study is derived from the conceptual framework discussed in Chapter 1. The study uses a quantitative-based exploratory design that uses both existing data sources and collected data sources using a specifically designed instrument in order to quantify the institutional financial aid process at the California Community Colleges.

\section{Research Design and Role of Researcher}

The research study uses a quantitative-based exploratory design and comparative analysis. A quantitative-base exploratory design allows the ability to test hypothesis questions while allowing the ability to address the unknowns of the research in circumstances where clear or previous theoretical models might not clearly outline the research path (McDavid \& Hawthorn, 2006). The study uses both existing data 
sources and collected data sources using a specifically designed instrument in order to quantify the institutional financial aid process at the California Community Colleges.

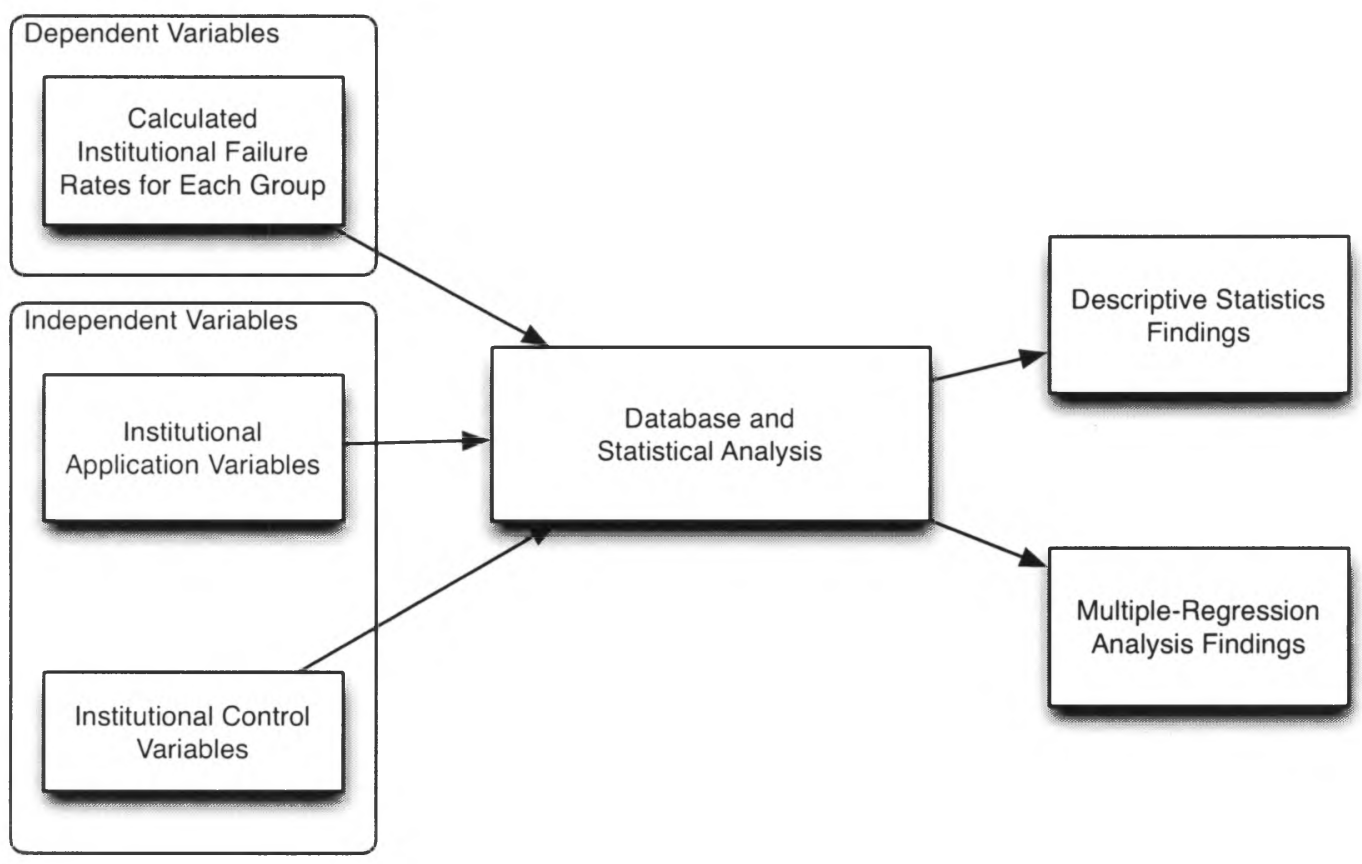

Figure 2. Research Design.

\section{The Dependent Variables}

The study started with the California Community College Chancellor's Office DataMart 2009-2010 data. The DataMart system identifies students who received financial aid and enrolled at the community college as well as students the college received a FAFSA for, but did not receive financial aid for a number of reasons. The DataMart identifies seven different reasons why a student did not receive financial aid. These include students who completed a FAFSA and 1) never enrolled or attended;2) 
completed the institutional application process; 3) were determined ineligible because they had no need; 4) were eligible for financial aid but no funds were available; 5) were not eligible for financial aid due to not making Satisfactory Academic Progress; 6) other reasons; and 7) unknown or uncollected. No schools reported option four, that a student was eligible but no funds were available. This data is reported by student counts by institution and further by a student's ethnicity at the institutional level.

\section{Application Default Rates}

This data allowed two application failure rates to be calculated. The first, and most restrictive, was the count of students who did not complete the financial aid application but still enrolled at the college divided by the sum of the students who received financial aid and the students who did not complete the process yet still enrolled.

Count of Students Who Did not Complete Financial Aid Application Process, Still Enrolled

Count of Students Who Did Complete Financial Aid Application Process and Enrolled

Count of Students Who Did not Complete Financial Aid Application Process, Still Enrolled

\section{Figure 3. Failure Rate Calculation I.}

This resulted in a failure percentage rate for both the institution for all students as well as failure percentage rates for each ethnicity group.

Additionally, a second failure percentage rate was calculated using a wider definition. This wider definition included the sum of students who never enrolled or attended, did not complete the process yet still enrolled, and those students disqualified 
due to lack of Satisfactory Academic Progress divided by the sum of those same students and the student who received financial aid.

\begin{tabular}{|c|c|c|c|c|}
\hline Count of Students & & Count of Students & & Count of Students \\
\hline Who Did Not & & Who Did Not & & o Did Not \\
\hline Complete Financial & + & Complete Financial & + & Complete Financial \\
\hline Aid Application & & Aid Application & & Aid Application \\
\hline Process, Never & & Process, Still & & Process Due to \\
\hline & & & & $\begin{array}{c}\text { Satisfactory } \\
\text { Academic Progress }\end{array}$ \\
\hline
\end{tabular}

\begin{tabular}{cccc}
\hline $\begin{array}{c}\text { Count of Students } \\
\text { Who Did Complete } \\
\text { Financial Aid } \\
\begin{array}{c}\text { Application Process } \\
\text { and Enrolled }\end{array}\end{array}$ & $\begin{array}{c}\text { Count of Students } \\
\text { Who Did Not } \\
\text { Complete Financial } \\
\text { Aid Application } \\
\text { Process, Never } \\
\text { Enrolled }\end{array}$ & $\begin{array}{c}\text { Count of Students } \\
\text { Who Did Not } \\
\text { Complete Financial } \\
\text { Aid Application } \\
\text { Process, Still } \\
\text { Enrolled }\end{array}$ & $\begin{array}{c}\text { Count of Students } \\
\text { Who Did Not }\end{array}$ \\
Complete Financial \\
Aid Application \\
Process Due to \\
Satisfactory
\end{tabular}

Figure 4. Failure Rate Calculation II.

This resulted in a failure percentage rate for both the institution for all students as well as failure percentage rates for each ethnicity group. The two definitions of application failure rates resulted in ten different dependent variables for the study, two for each of the five groups.

Independent Variables

The independent variables were gathered for both the DataMart system, federal financial aid sources on the institution, and a financial aid audit instrument created to consistently measure the steps of the institutional application process. The design and testing of the instrument is further discussed in the instrumentation section of this chapter below.

Data from the DataMart system used in the study was the financial aid-staffing ratio based on full-time equivalent (FTE) and percentage of students on Pell grants. This 
information is reported to the DataMart and includes FTE for administrators, nonteaching academic support and operations assigned to the financial aid office. This FTE was used to calculate a student to staff ratio by taking the total number of students who received financial aid divided by FTE. The percentage of students who received Pell grant information was based on taking the count of the Pell grant awards (broken out by ethnicity) divided by the count of students who received any type of financial aid (broken out by ethnicity). This was also calculated for all combined ethnicity groups for the percentage of financial aid students who received a Pell grant at an institution.

Federal financial aid data included in the study was the 2008 cohort default rate for each institution. The cohort default rates measures how many students who entered repayment on their student loans in a given federal fiscal year end up defaulting on any of their loans that they borrowed from the institution within a given time period. Two cohort default rates are currently calculated by the Federal Department of Education. The first cohort default rate is based on two federal fiscal years and the second is a based on three federal fiscal years. An institution is currently held responsible for the two-year cohort default rate and will soon be held responsible for the three-year default rate.

The institutional application progress involves a multitude of steps or actions a student must take in order to successfully complete the process. A college financial aid office, either through intentional design or unintentional design, creates a critical path 
for students to successfully complete the institutional application process. The process starts with a student completing the FAFSA and including the college's federal school code on the application. The process ends with a student receiving a financial aid award letter and enrolling in courses at the college. The time span for this process can be anywhere from a few days to upwards of 18 months. A sample of this critical path is below in Figure 5.

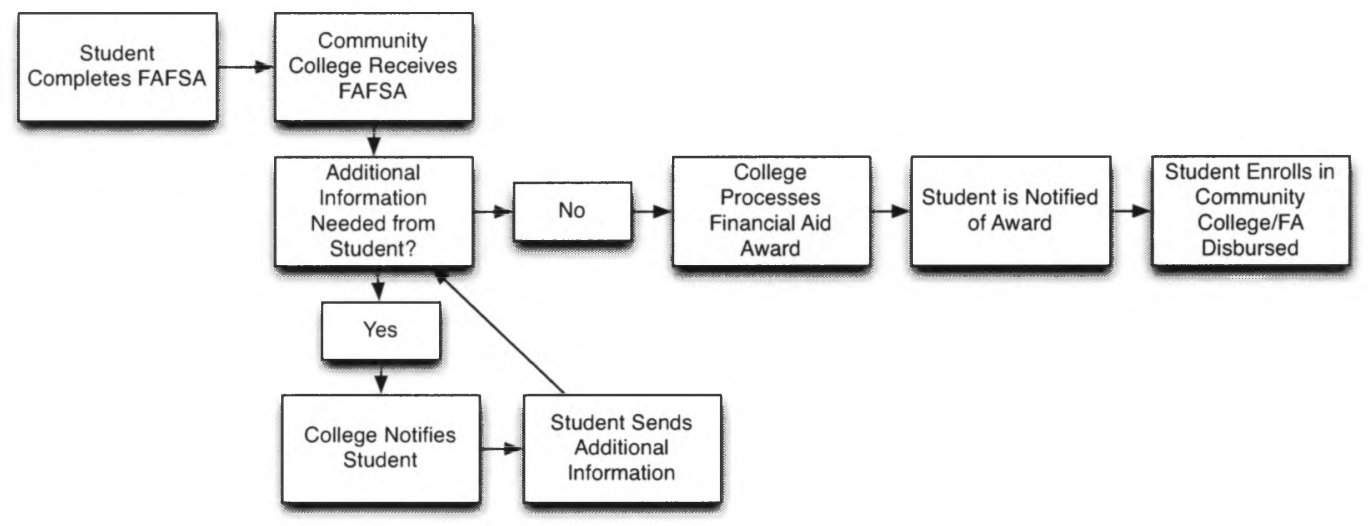

Figure 5. Example Financial Aid Application Critical Path

In addition to this critical path, a college financial aid office creates feedback loops that assist students to either maintain the critical path or to assist students back on to the critical path. Again, these feedback loops can be by design or not by design. A sample of the feedback loops that a college financial aid office may have during the critical path is below in Figure Y. 


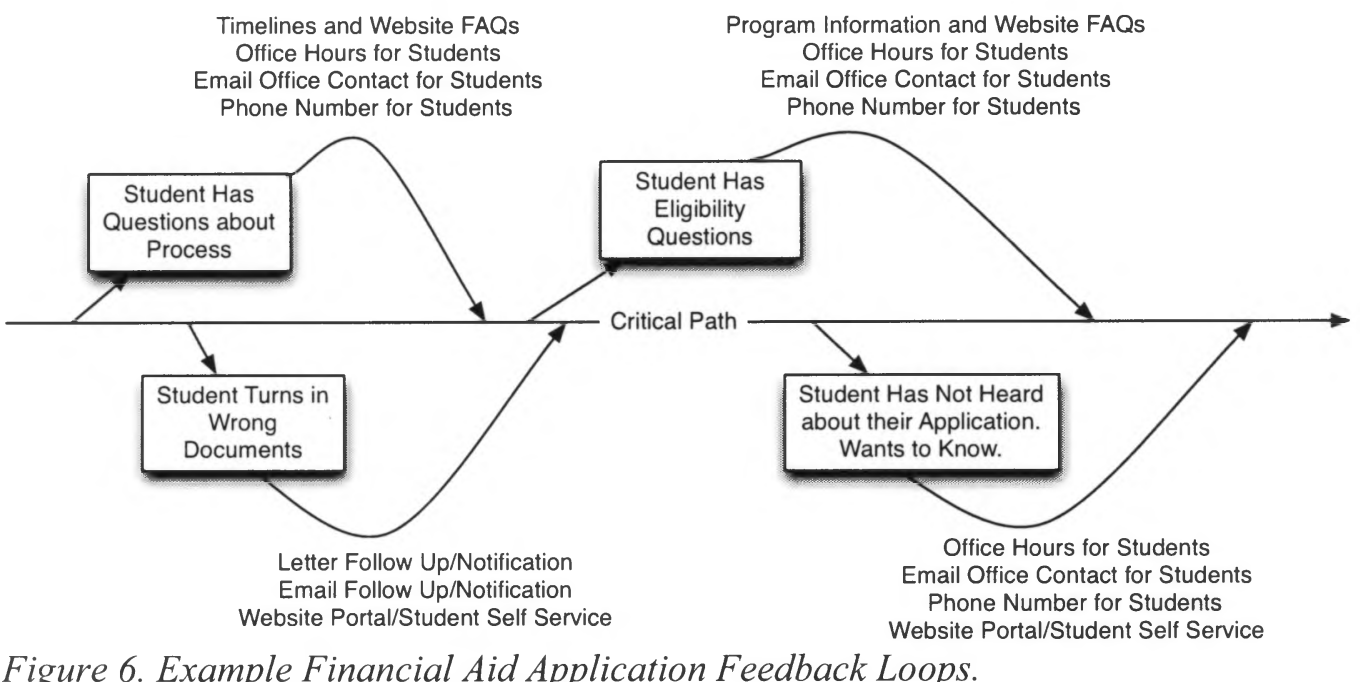

The California Community College institutional application shares a number of similarities and many differences. In order to collect this information, an instrument was developed in order to measure both the critical path and the feedback loops developed by the college. This instrument was used for the majority of the independent variables used in the study and the design of the instrument is fully described below in this chapter and included in Appendix A.

The following independent variables were collected using the Financial Aid Audit instrument:

- Is There a Financial Aid Website? - Answered Yes or No

- Number of clicks to get from the main college website to the mail financial aid website. - Scale

- Is there a welcome message from the director/dean of financial aid? - Answered Yes or No 
- Monday Office Hours - Open Time and Close Time (with any noted closures for lunch).

- Tuesday Office Hours - Open Time and Close Time (with any noted closures for lunch).

- Wednesday Office Hours - Open Time and Close Time (with any noted closures for lunch).

- Thursday Office Hours - Open Time and Close Time (with any noted closures for lunch).

- Friday Office Hours - Open Time and Close Time (with any noted closures for lunch).

- Saturday Office Hours - Open Time and Close Time (with any noted closures for lunch).

- Sunday Office Hours - Open Time and Close Time (with any noted closures for lunch).

- Does the financial aid office have the same office hours and counseling hours?

- Monday Counseling Hours - Open Time and Close Time (with any noted closures for lunch).

- Tuesday Counseling Hours - Open Time and Close Time (with any noted closures for lunch).

- Wednesday Counseling Hours - Open Time and Close Time (with any noted closures for lunch).

- Thursday Counseling Hours - Open Time and Close Time (with any noted closures for lunch).

- Friday Counseling Hours - Open Time and Close Time (with any noted closures for lunch). 
- Saturday Counseling Hours - Open Time and Close Time (with any noted closures for lunch).

- Sunday Counseling Hours - Open Time and Close Time (with any noted closures for lunch).

- Can a student contact the financial aid office via phone, email, in-person, instant message, social media (Facebook, Twitter, etc.), financial aid email/mailed newsletter - For each contact option, Yes or No.

- Is there a method for students to submit comments/suggestions to the office? Yes or No.

- Is there information on the financial aid office about the application process, BOG waiver, grants (state and federal), Satisfactory Academic Progress, outside grants/scholarships, loans, verification process, and frequently asked questions For each option, Yes (internal webpage), Yes (links to outside website), Yes (PDF or word document), or No.

- How many FAQs does the FAQ page have - Count of the number of questions.

- Financial aid forms are online for verification, Satisfactory Academic Progress, BOG Waiver, dependency override, and financial aid petition (change of circumstances) - For each option, Yes (fillable PDF or online "eform"), Yes (not PDF fillable or not online "eform"), No.

- What languages, outside of English, does the financial aid office explicitly support? - Spanish, Chinese, Vietnamese, Korean, Russian, Japanese, Other (with fill in the blank).

- How are these languages supported? - Website Information, Financial Aid Forms, Phone and/or email support.

- What methods are used to explain the application process? - Written text, timelines, diagrams, audio (recording), video, and other (with fill in section).

- Does the financial aid office have a priority deadline? - Yes, No, or Not Specified. 
- If Yes to priority deadline, what is the priority deadline (in Month and Day format)?

- Is there an institutional application deadline? - Yes, No, or Not Specified.

- If Yes to institutional application deadline, what is the priority deadline (in Month and Day format)?

- How are students notified that they were selected for verification? - Letter, email, online portal/website, student has to contact the financial aid office, or not indicated.

- How can students turn in verification documents? - In-person, email, fax, mail, online (website), or other (fill-in).

- Does the college verify all students? - Yes or No.

- How does the college notify the student of verification follow up? - Student needs to check with the office, student needs to check online, email notification, mailed letter or not identified.

- Are student given a timeline between applying and notification? - Yes or No.

- If yes to student given a timeline, what is the timeframe (in weeks)?

- How are students sent award notifications? - Mailed award letter, email award letter, online award letter, not specified.

- Does the financial aid office do additional outreach to students? - Cash for college nights/FAFSA completion session, high school sessions/nights, incentive programs, connection between application and enrollment, and other (fill-in).

\section{The Researcher}

The researcher is a financial aid professional who works for a private non-profit undergraduate and graduate institution in California. The researcher has extensive 
experience and knowledge of the financial aid application process from his educational background and work in the profession. He is a member of the professional financial aid community at both the state, regional and federal level. This financial aid community also contains many of the financial aid professionals who work in the California Community Colleges at both the administrative and staff levels. He has worked directly with many of the professional administrators who run the financial aid programs at the community colleges through his previous and current work. But he is neither directly connected to any of the community colleges studied in the dissertation nor the California Community College Chancellor's Office.

\section{Setting and Sample}

The target population was the complete set of all 112 California Community Colleges and their financial aid application processes. The California Community College Chancellor's Office DataMart system contained 51 colleges that reported data sets containing the number of students who both completed the financial aid application process at the school and enrolled during the 2009-2010 school year and those students who started the financial aid application process, did not complete it, and still enrolled during the 2009-2010 school year. This represented $45.5 \%$ of all of the California Community Colleges as part of the sample. The sample size represents nearly half of the California Community Colleges. Table 3 compares the demographics of all of the California Community Colleges and the 51 colleges included in the study. 
Table 3.

Comparison of data sample and all California Community Colleges.

\begin{tabular}{lcc} 
Demographic & Study Sample & $\begin{array}{c}\text { All California } \\
\text { Community } \\
\text { Colleges }\end{array}$ \\
\hline Enrollment (Mean) & 24,687 & 19,242 \\
Students Received & 9,685 & 9,136 \\
Financial Aid (Mean) & & \\
$\%$ Male & $47 \%$ & $46 \%$ \\
$\%$ Female & $53 \%$ & $54 \%$ \\
$\%$ African- & $8 \%$ & $9 \%$ \\
American Students & & \\
$\%$ Asian Students & $11 \%$ & $14 \%$ \\
$\%$ Hispanic Students & $37 \%$ & $34 \%$ \\
$\%$ White Students & $45 \%$ & $40 \%$ \\
\hline
\end{tabular}

The 51 colleges were selected because they had fully reported data to the DataMart system. If all 112 California Community College had fully reported data for this category of students, this study would have reviewed all of the college's financial aid application processes in order to increase the $\mathrm{N}$ value. Based on the demographics and the large percentage of the California Community Colleges included in the sample, the sample will be representative, and therefore, generalizable to the California Community Colleges. 
The DataMart system reports students by a number of different ethnicities. The 51 colleges that had reported data only consistently reported ethnicities for AfricanAmerican, Asian, Hispanic and White students across all of the colleges. The sample was limited to these four groups and totals were recalculated for each institution based on these four groups. While this is a limitation, it was required to maintain consistency across the 51 colleges.

\section{Ethics and Protection of Human Subjects}

Minimal risk exists to human subjects in the dissertation. The data collected from the community colleges is at the institutional level and the student specific financial aid application status data is aggregated to the institutional level. No individual study identifying information was ever collected at any point in the research. None of the institutions were named individually and results were reported in a manner where no individual institution could be identified.

Additionally, to minimize risk, all research data was stored in a locked cabinet/desk in a secure location and/or in a password encrypted electronic data source. All data will be destroyed one year after successful completion of the program requirements for the degree.

\section{Instrumentation}

The instrument used to collect the data on the financial aid application process was created for the purposes of this dissertation due to no other comprehensive 
instrument being available. The instrument is included in Appendix A. The instrument was developed by first outlining the steps a student should complete during the financial aid application process at the institutional level. This outline was used to develop first a workflow of the desired path an institution desires a student follow in order to successfully complete the process (See Figure 5). A second workflow was then developed outlining the feedback loops that a financial aid office could put in place to assist a student back on to the desired path (See Figure 6). Both the desired path workflow and the feedback loop workflow were informed by the literature on the financial aid process and best practices (see - references, references, references).

Both the desired path workflow and the feedback loop workflow was then sent out to five financial aid professionals who have worked at community colleges inside and outside of California for feedback. This feedback was collected and the resulted in a refining of both the workflows and the feedback loops.

Next, the two workflows were formed into a questionnaire that the researcher could use to measure both the desired path and feedback loops. The design of the questionnaire focused on answering basic descriptive data about a financial aid office's application process. The questionnaire was grouped based on topic areas that included office hours, counseling hours, student access to the office, financial aid information available to students, language support, the application process, the verification process, the award notification process, office outreach to students. Each one of these sections 
had sub-questions. This questionnaire was then pilot tested by the researcher for operational efficiency with five community colleges and refined based on the pilot.

Finally, the questionnaire was sent back to five financial aid professionals who have worked at community colleges inside and outside of California for feedback, including having them assess their own community college Financial Aid Office process. The feedback was collected and a further revision of the questionnaire was completed. The questionnaire was then set up as a Google document form in order to allow the research a consistent platform for data collection. The questionnaire and variable codebook is included in Appendix A and B, respectfully.

The validity of the instrument comes from the development and feedback processes. The instrument was first grounded in the financial aid application desired path and feedback loops as well as the literature on the financial aid process and recommended best practices (as outlined in Chapter 2). Next, the validity was further established by the two rounds of outside review by financial aid professionals who work in the community college environment and are experts on the day-to-day operations of their institutional application process and the components of that application process that might affect a student's success through that process.

The reliability of the instruments is established through two primary functions as each web site is reviewed and the instrument completed. First, the instrument used primarily yes or no type questions. Examples of this include, "Is there a financial aid 
website?", "What are the office hours on Mondays?", and "Can a student turn in a financial aid form via fax?" These types of questions increase reliability by reducing subjective considerations. Second, to increase reliability, only the researcher collected the data on the 51 California Community Colleges using the same set up each time.

\section{Data Collection}

Data collection started with the California Community College Chancellor's Office DataMart system. The DataMart system contained the data on the financial aid application of all 112 California Community Colleges for the 2009-2010 school year. The 51 California Community Colleges with full data sets containing the number of students who both completed the financial aid application process at the school and enrolled during the 2009-2010 school year and those students who started the financial aid application process, did not complete it, and still enrolled during the 2009-2010 school year.

The researcher using the financial aid audit instrument reviewed each of the 51 colleges' financial aid websites. The information was entered into the instrument and then input into a database system. Any instrument question that was not clear or could not be identified from the college's financial aid office website was left blank and submitted without this information. Originally, the researcher believed that the vast majority of information on the instrument would be able to be collected from the college's financial aid website. This often turned out to not be the case. Examples of 
data that could not be identified from a college's website included office hours that stated a student must call to get this information and the types of financial aid forms available to students which were only available behind the college's online student portal.

After all 51 colleges' financial aid audit information was collected, that database was copied and stored in a separate file. This created a working copy of the database to go back to the colleges that had missing information. This missing information was highlighted and then the researcher contacted each of those financial aid offices to collect the missing information. A total of 10 colleges were contacted during this second phase in order to enter the missing information. The researcher called the main financial aid office number listed on their website, identified himself as a graduate student working on a study about the financial aid application process, and that he was collecting basic information on how a student would apply for financial aid. The questions involved office hours on a certain day and how a student submitted a verification form. These questions are in line with typical questions a frontline financial aid representative, who talks to student and parents, receives each day. It often took more than one phone call attempt to reach a financial aid person but they provided the information since it was in line with typical questions students and parents ask each day. 
When all of the additional colleges were contacted and missing information was added, the compare function of Excel was used to compare the original database to the new database with the additional information to confirm no original data was changed or corrupted during the manual addition process of the missing information.

Almost all of the questions from the financial aid audit instrument were in the form of yes/no or multiple-choice options. For analysis, "Yes" answers were assigned the value of one (1) and the "No" answers were assigned the value of zero (0). For multiple choice question data it was assigned an ordinal value of zero (0), one (1), two $(2), \ldots$ The typical case for this was the question about financial aid forms and the answer choices were: Yes (fillable PDF or online "eform"), Yes (not PDF fillable or not online "eform"), No. In this case Yes (fillable PDF or online "eform") was assigned a value of two (2), Yes (not PDF fillable or not online "eform") was assigned a value of one (1), No was assigned a value of zero (0).

Many of the data points are inter-related within the financial aid application process to either the critical path or the feedback loops and could be combined into an index. For instance, if a student can contact the financial aid office via the phone it might also be assumed the student can also contact the office in-person and via email, and therefore that the level of student access would increase. The following financial aid indices were created:

- Index of how many ways can a student contact the financial aid office. 
- Index of information on financial aid process and funding options.

- Index of availability of financial aid forms.

- Index of how student are notified of being selected for verification.

- Index of how students can turn in verification documents.

- Index of how students are notified of verification following up.

- Index of how students are sent award notifications.

The financial aid audit data was then combined with the financial aid student/staff FTE ratio, percentage of students receiving Pell grants (combined and broken out for the four ethnicities groups) and the two-year and three-year federal loan cohort default rate for each institution. Finally, the ten dependent variables of failure rate (to be tested individually) were added to the database.

Seven colleges were removed before analysis because they were missing data for one or more ethnicity group application failure rates and the resulting calculated institutional failure rates were below one percent. One additional college was removed before analysis because it had an institutional application failure rate over $50 \%$ and represented a special program for working adults within a community college district. These outliers were removed in order to maintain consistency within the study for the dependent variable. This reduced the sample size to 43 colleges. 


\section{Data Analysis}

The last study to present a comprehensive state of the California Community College financial aid application process was based on a survey conducted over a decade ago by the California Community College Chancellor's Office, so additional attention has been applied to descriptive statistics in order to present a current state of the colleges' financial aid application process.

The complete database was loaded into SPSS (statistical analysis software) to run multiple regression analysis on each of the independent variables compared to the dependent variables. The methodology used for the selection of the independent variables was driven by theory outlined in Chapter Two that was believed to influence student success and failure through the institutional application process in line with the primary and secondary research question. A regression model for each one of the dependent variables was separately run so that comparisons of the effects of the independent variables could be made across dependent variables. 


\section{Chapter Four: Report of Findings \\ Overview}

This chapter is divided into two sections. The first section presents descriptive statistics about the state of the institutional financial aid application process at the 43 California Community Colleges included in the study. The second section presents findings from the statistical analysis of the factors of the institutional application process and student failure rates through those processes. The first section is presented for the purposes of providing a current state of the California Community Colleges financial aid application process. The second section directly addresses the two research questions and hypothesis presented in Chapter 1.

\section{The Findings I - State of the Institutional Financial Aid Application}

The range of students who receive financial aid and who receive a Federal Pell Grant (the major source of grant funding from the Federal Department of Education) is wide across institutions. On the low end, only $20 \%$ of financial aid students at an institution receive a Federal Pell Grant. On the high end, nearly $70 \%$ of financial aid students at an institution receive a Federal Pell Grant. The figure below presents the full range of institutions in the study by percentage of financial aid students receiving a Pell Grant. 


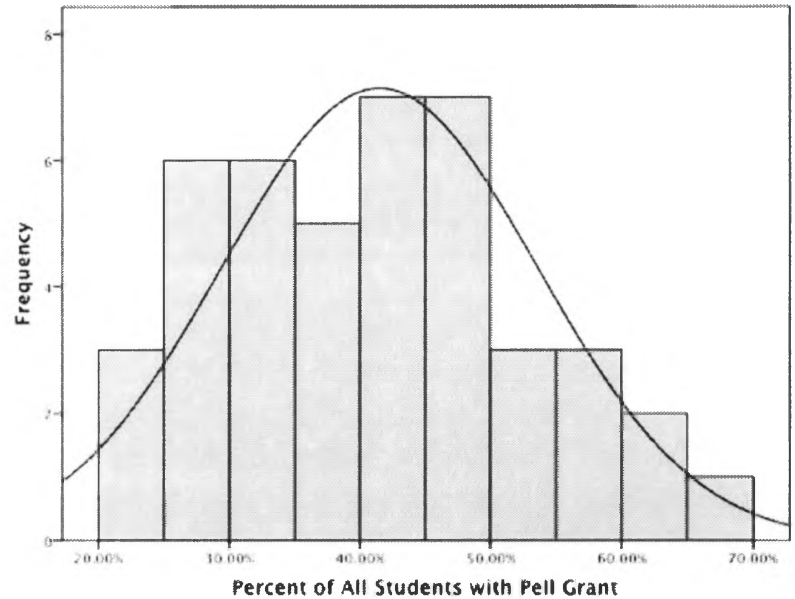

Figure 7. Count of institutions by percentage of students with Pell Grants.

The distribution for the percentage of student receiving a Pell Grant at the colleges in the study had a mean of $41.5 \%$ and standard deviation of $12.0 \%$. The distribution is a normal distribution with a peak between $40 \%$ and $50 \%$ of students receiving a Pell Grant.

\section{Distribution of Failure Rates}

Institutional Application Failure Rates By Ethnicity-Calculation I

The range of students who successfully complete the institutional financial aid application process after completing a FAFSA also varies widely by ethnicity. The study used two different definitions of the institutional financial aid application failure rate. The first one used only those students who completed a FAFSA, failed to complete the institutional application process, and still enrolled in the college. The range of this failure rate varied not only by institution, but also ethnicity. Figure 8 below shows the 
range of the colleges in the study and their student application failure rate for still enrolled African-American students.

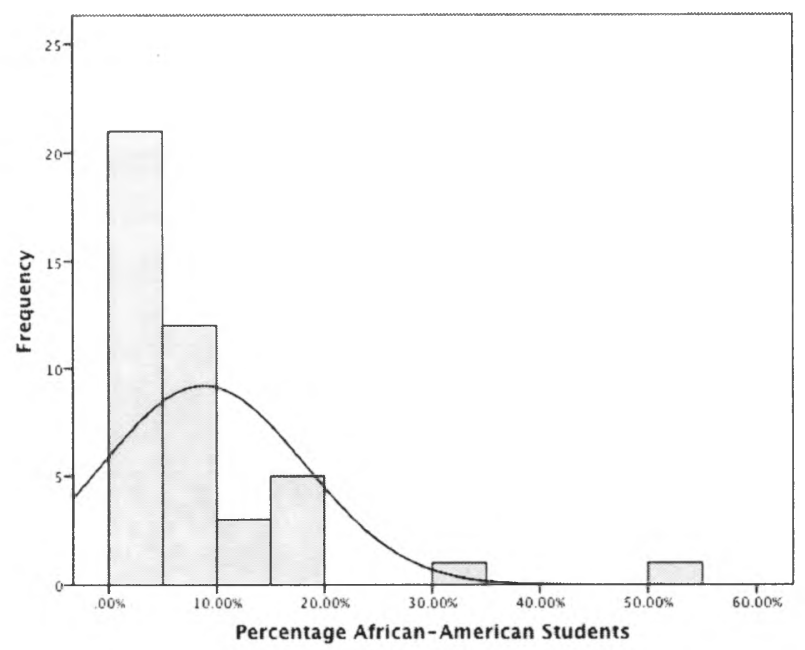

Figure 8. Count of institutions by application failure rate that enrolled for AfricanAmerican students

The mean for the institutional failure rate for African-American students was $8.8 \%$ with a standard deviation of $9.3 \%$ due to the long tail of the distribution for a few schools that had failure rates above $30 \%$. The largest groups of schools experienced between a $0 \%$ and $10 \%$ failure rate for African-American students.

Figure 9 below shows the range of the colleges in the study and their student application failure rate for still enrolled Asian students. 


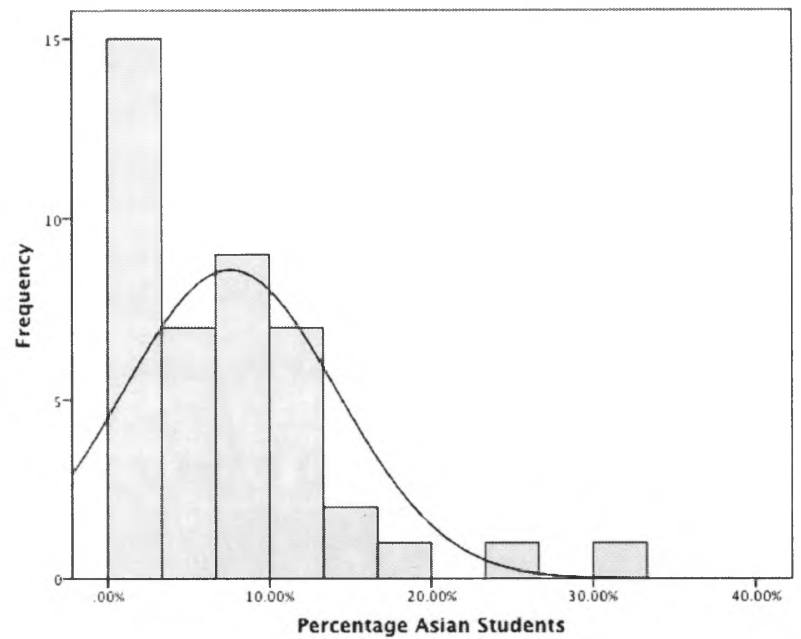

Figure 9. Count of institutions by application failure rate that enrolled for Asian students.

The mean for the institutional failure rate for Asian students was $7.6 \%$ with a standard deviation of $6.7 \%$. The largest groups of schools were between a $0 \%$ and $20 \%$ failure rate for Asian students. Compared to the African-American students, Asian students had more colleges above a $10 \%$ failure rate, but only one college above $30 \%$ compared to two for African-American students.

Figure 10 below shows the range of the colleges in the study and their student application failure rate for still enrolled Hispanic students. 


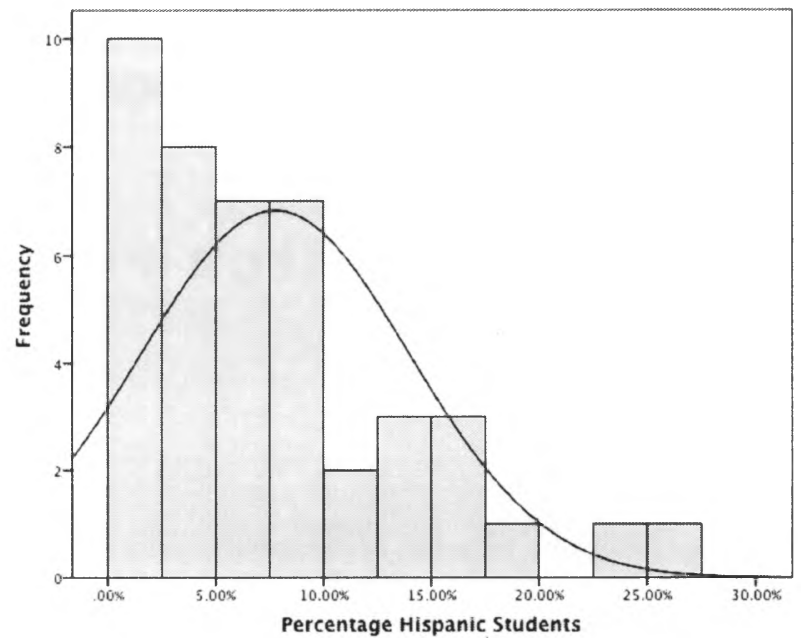

Figure 10. Count of institutions by application failure rate that enrolled for Hispanic students.

The mean for the institutional failure rate for Hispanic students was $7.8 \%$ with a standard deviation of $6.3 \%$. The largest groups of schools were between a $0 \%$ and $20 \%$ failure rate for Hispanic students. Compared to the African-American and Asian students, Hispanic students had only two colleges with failure rates above $20 \%$ and both were below $30 \%$.

Figure 11 below shows the range of the colleges in the study and their student application failure rate for still enrolled White students. 


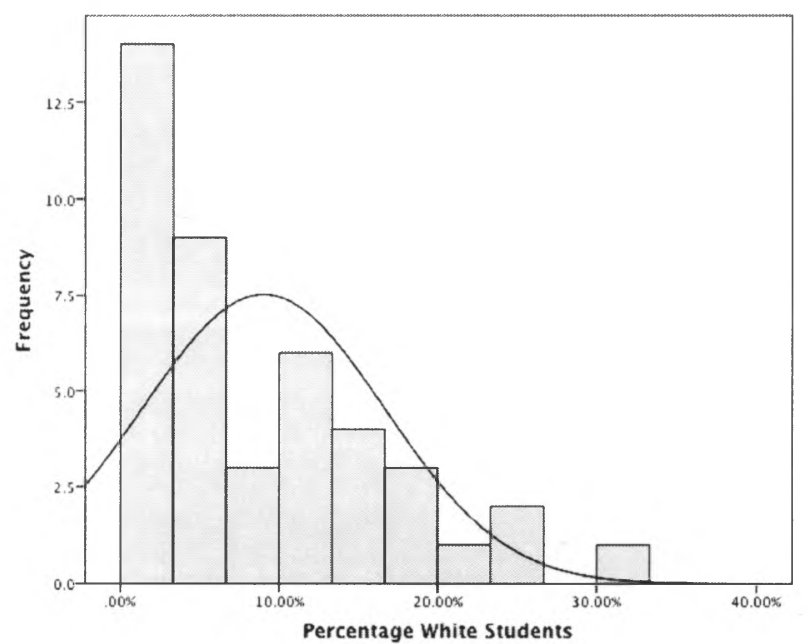

Figure 11. Count of institutions by application failure rate that enrolled for White studerits.

The mean for the institutional failure rate for White students was $9.0 \%$ with a standard deviation of $7.6 \%$. The largest groups of schools were between $0 \%$ and $20 \%$ failure rate for White students. Compared to the African-American and Asian students, White students had only three colleges with failure rates above $20 \%$ of those colleges, only one was over $30 \%$.

Figure 12 below shows the range of the colleges in the study and their student application failure rate for still enrolled all four ethnicity student groups, combined. This graphic, when compared to each ethnicity group above, shows the variance in the first measure of the institutional failure rate. 


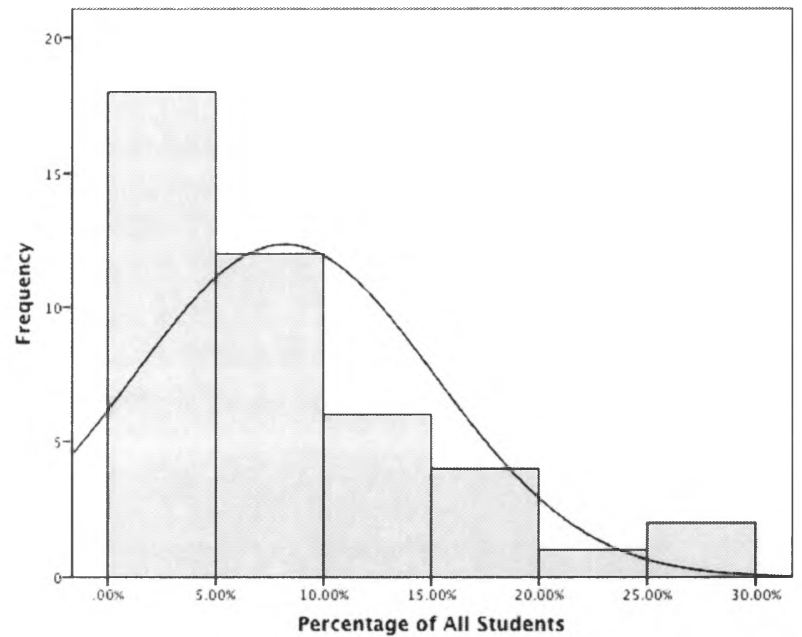

Figure 12. Count of institutions by application failure rate that enrolled for all students.

The largest group of schools has failure rates between $0 \%$ and $5 \%$. The mean for these colleges is $8.2 \%$ with a standard deviation of $6.9 \%$. There still remains a large group of schools with failure rates between $5 \%$ and $10 \%$. In the study, 13 of the 43 colleges had failure rates for their overall student population above $10 \%$. The distribution of the failure rates is a normal distribution. Comparing all of the student group failure rates based on the first calculation to each student ethnicity group, it reduces any one extreme failure rate. The all student group failure rates obscures some the variability in each of the student ethnicity groups' failure rates.

\section{Institutional Application Failure Rates By Ethnicity-Calculation II}

The second measure of the institutional application failure rate used the students who did not complete the application but still enrolled, the students who did not complete the application process and did not enroll, and the students who applied but 
did not complete the process due to not making satisfactory academic progress. This measure of the failure rate produced a wider distribution of institutional failure rates both based on student ethnicity and for all of the students. The overall application failure rate results are described and displayed below in Figures 13, 14, 15, and 16 for African-American, Asian, Hispanic and White students, respectively.

Figure 13 below shows the range of the colleges in the study and their student application second calculated failure rate for African-American students. The mean institutional failure rate percentage was $20.3 \%$ with a standard deviation of $13.7 \%$. The mean was over twice as high for African-American students compared to the first calculated failure rate and a wider standard deviation. There were still a number of colleges in the study that maintained failure rates between $0 \%$ and $10 \%$, but a large number of schools shifted higher as represented by doubling of the mean failure rate. The concentration of the school also grew wider as represented by the standard deviation increasing from $9.3 \%$ to $13.7 \%$. The distribution of the colleges' failure rates still follows a normal distribution with the exception of one college having a failure rate above $50 \%$ for African-American students. 


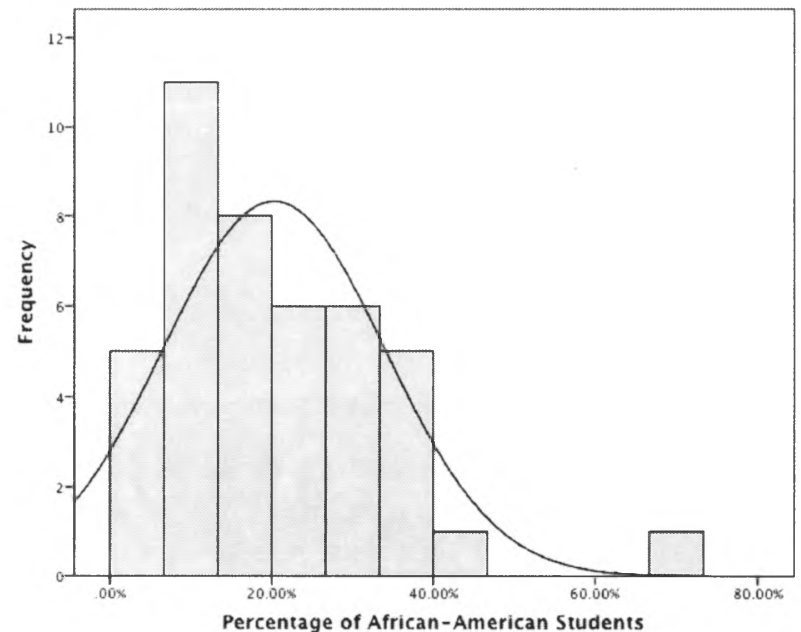

Figure 13. Count of institutions by overall application failure rate for African-American students.

Figure 14 below shows the range of the colleges in the study and the second calculated failure rate for Asian students. 


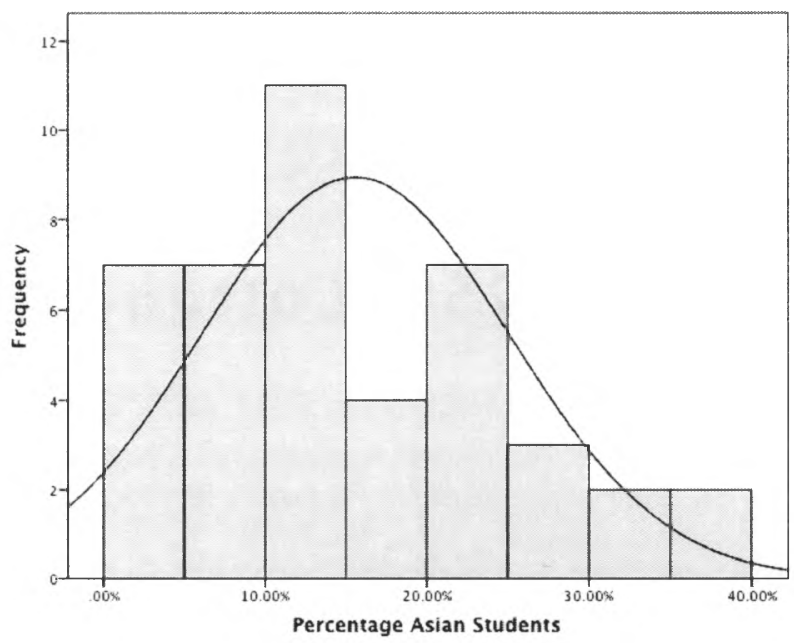

Figure 14. Count of institutions by overall application failure rate for Asian students.

The mean institutional failure rate percentage for Asian students was $15.6 \%$ with a standard deviation of $9.6 \%$. The mean failure rates while lower then the failure rate for African-American students was still over twice as high for Asian students compared to the first calculated failure rate and a wider standard deviation. There were still 14 colleges in the study that maintained failure rates between $0 \%$ and $10 \%$, but the remaining 29 colleges in the study had failure rates for Asian students over $10 \%$. Four of these colleges had higher then $30 \%$ failure rates. Again, the concentration of the school also grew wider as represented by the standard deviation increasing from $6.7 \%$ to $9.6 \%$. The distribution of the colleges' failure rates still follows a normal distribution.

Figure 15 below shows the range of the colleges in the study and the second calculated failure rate for Hispanic students. 


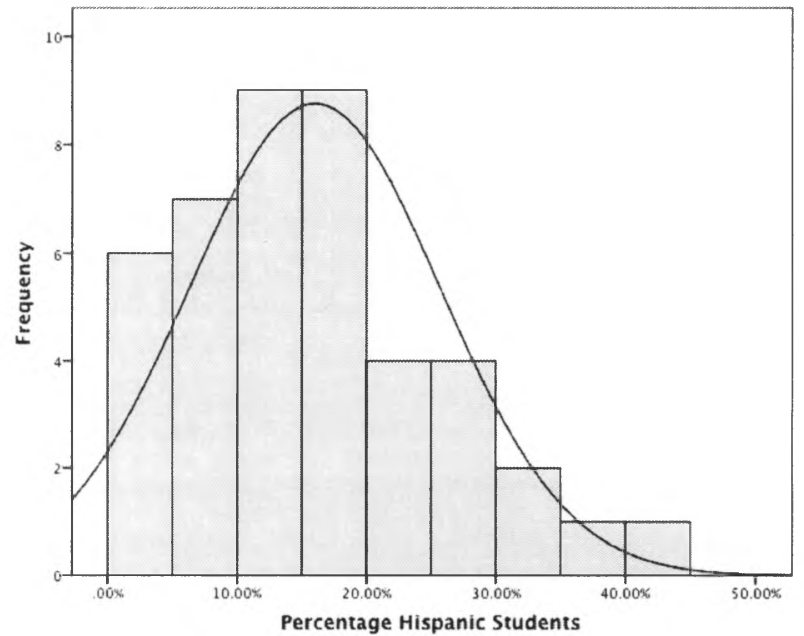

Figure 15. Count of institutions by overall application failure rate for Hispanic students.

The mean institutional failure rate percentage for Hispanic students was $16 \%$ with a standard deviation of $9.8 \%$. The mean failure rate for Hispanic students was in line with Asian students but still lower then African-American students. The second calculated failure rate for Hispanic students was still twice has high as the first calculated failure rate. There were still 13 colleges in the study that maintained failure rates between $0 \%$ and $10 \%$, but the remaining 30 colleges in the study had failure rates for Hispanic students over $10 \%$. Four of these colleges had higher then $30 \%$ failure rates, with one college having a failure rate higher then $40 \%$. Again, the concentration of the school also grew wider as represented by the standard deviation increasing from $7.6 \%$ to $9.8 \%$. The distribution of the colleges' failure rates still follows a normal distribution.

Figure 16 below shows the range of the colleges in the study and their student application second calculated failure rate for White students. 


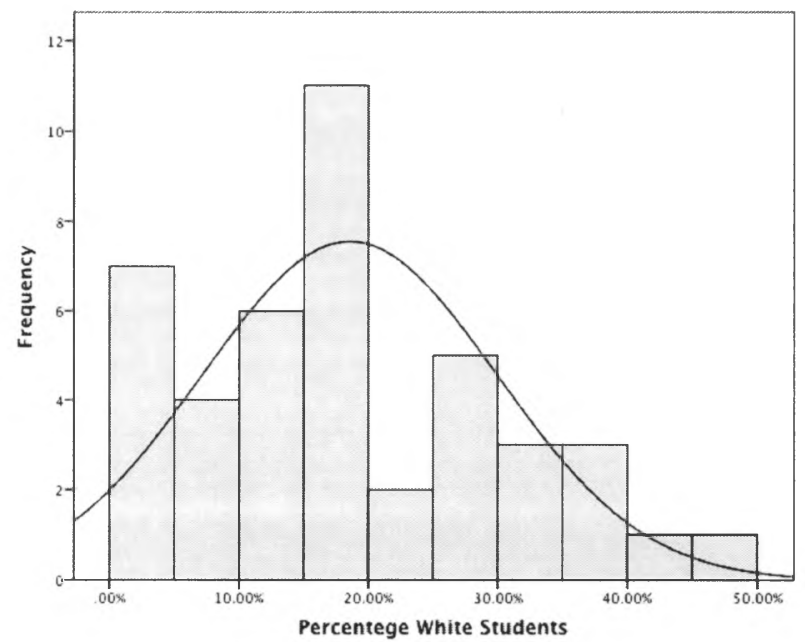

Figure 16. Count of institutions by overall application failure rate for White students.

The mean institutional failure rate percentage for White students was $18.6 \%$ with a standard deviation of $11.4 \%$. The mean failure rate and standard deviation for White students were second highest and only lower to African-American students. While African-American, Asian and Hispanic student second calculated failure rate had a normal distribution, White students show at least three different peaks in their distribution. While the number of colleges in the overall distribution is small, a noticeable grouping of colleges occurs at in the $0 \%$ to $5 \%$, the $15 \%$ to $20 \%$ and the $25 \%$ to $30 \%$. The $25 \%$ to $30 \%$ is in line with a normal distribution curve, only two schools were between $20 \%$ and $20 \%$. This distribution might suggest that there are a group of colleges meeting White students needs in completing the institutional application based on the second calculated failure rate. Another group of colleges are in line with the other ethnicity groups in the $25 \%$ to $30 \%$ area, while another group of colleges spread 
out in the $35 \%$ to $50 \%$ failure rate range. This could mean that there are number of colleges not meeting their student needs in order to complete the institutional application.

Figure 17 below shows the range of the colleges in the study and their overall student application failure rate that still enrolled for all four ethnicity student groups. This graphic, when compared to each ethnicity group above, shows the variance in the second measure of the institutional failure rate.

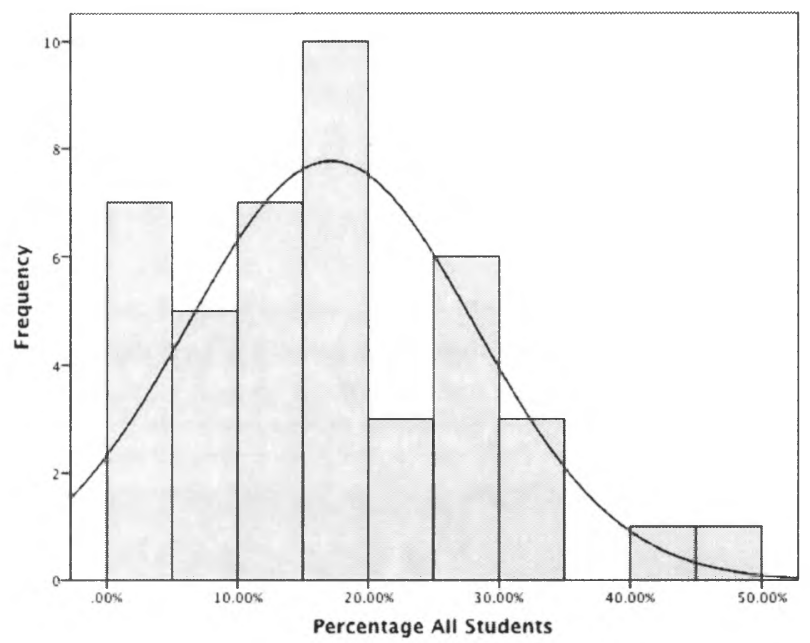

Figure 17. Count of institutions by overall application failure rate for all students.

The mean institutional failure rate percentage for all student groups was $17.0 \%$ with a standard deviation of $10.7 \%$. Similar to the distribution of the failure rates for White students, a noticeable grouping of colleges occur at the $0 \%$ to $5 \%$, the $15 \%$ to $20 \%$ and the $25 \%$ to $30 \%$. The $25 \%$ to $30 \%$ is in line with a normal distribution curve; only three colleges were between $20 \%$ and $25 \%$. This distribution might suggest that there is a 
group of colleges meeting the overall student group needs in completing the institutional application based on the second calculated failure rate. Another group of colleges are in line with the other ethnicity groups in the $25 \%$ to $30 \%$ area, while another group of colleges spread out in the $35 \%$ to $50 \%$ failure rate range. For the two colleges in the $40 \%$ to $50 \%$ failure rate, it approaches the point where nearly half of the students who complete a FAFSA and apply for financial aid never complete the process. The odds approach that of a coin flip.

\section{Institutional Application Implementation}

\section{Student to Staff Ratios}

A number of descriptive statistics about the current state of the California Community College institutional application process are worth noting. The first is the ratio of financial aid students to community college administrators, staff, and instructors assigned to the financial aid office. This is known as the student to staff ratio and expressed in $\mathrm{x}$ number of students per financial aid staff member. The ratio is based on staff FTE in Figure 18. 


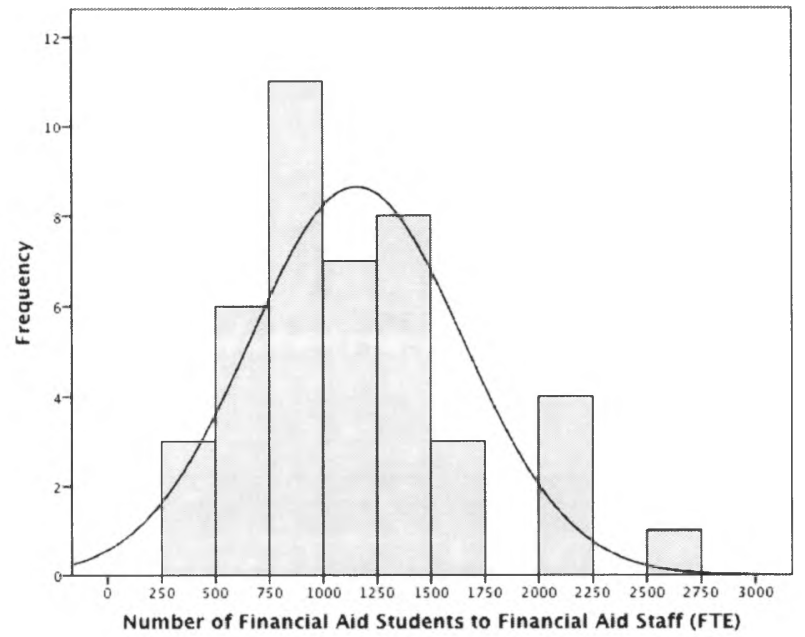

Figure 18. Count of institutions by ratio of financial aid students to financial aid staff FTE.

The largest grouping of schools is between 750 and 1000 students per financial aid staff FTE. The mean financial aid students per financial aid staff FTE were 1156 students per staff member with a standard deviation of 496. The distribution of colleges follows a normal curve. Five colleges in the study had student to staff FTE nearly twice as high or more than the mean.

\section{Number of Clicks}

Another consideration for student access is the number of "clicks" required for a student to get from the colleges main webpage to the first financial aid website. The range in the study was between one "clicks" to three "clicks". The mean number of "clicks" required of the colleges in the study was 1.5 "clicks" with a standard deviation of .6. The largest number of colleges, 25 , only required one "click" to get to their financial aid page on their website. Only two colleges required three "clicks" to get to 
their financial aid information.

\section{Hours of Operations}

A financial aid office's hours of operations can be measured by either the number of hours the office is open or by the number of hours the office allows students to meet with a member of the financial aid office. Table 4 shows the descriptive statistics (minimum hours, maximum hours, mean hours and standard deviation of the hours) of institutions in the study and their weekly total of "normal" office hours. Normal office hours were defined at the total number of hours the financial aid office was open between 7:30 AM and 5:00 PM each day in the course of a week. Table 4 also shows the descriptive statistics (minimum hours, maximum hours, mean hours and standard deviation of the hours) of institutions in the study and their weekly total of "outside normal" office hours. Outside normal office hours were defined as the total number of hours the financial aid office was open before 7:30 AM or after 5:00 PM each day in the course of a week.

Table 4.

Descriptive statistics of institutions by weekly total of "normal" office hours.

\begin{tabular}{lcc}
\hline & $\begin{array}{c}\text { Normal" Office } \\
\text { Hours }\end{array}$ & $\begin{array}{c}\text { Outside } \\
\text { "Normal” Office } \\
\text { Hours }\end{array}$ \\
\hline Minimum Hours & 26.0 & 0.0 \\
Maximum Hours & 45.0 & 8.0 \\
Mean Hours & 38.6 & 2.6 \\
Standard Deviation & 4.7 & 2.4 \\
\hline
\end{tabular}


The second measure of office hours is the hours that a student could meet with a member of the financial aid office. These are commonly referred to as counseling hours. Table 5 shows the descriptive statistics (minimum hours, maximum hours, mean hours and standard deviation of the hours) of institutions in the study and their weekly total of "normal" counseling office hours. Normal counseling office hours are defined as the total number of hours the financial aid office was open for student counseling between 7:30 AM and 5:00 PM each day in the course of a week. Table 5 also shows the descriptive statistics (minimum hours, maximum hours, mean hours and standard deviation of the hours) of institutions in the study and their weekly total of "outside normal" counseling office hours. Outside normal counseling office hours are defined as the total number of hours the financial aid office was open before 7:30 AM or after 5:00 PM each day for student counseling in the course of a week.

Table 5.

Descriptive statistics of institutions by weekly total of "outside normal" office hours.

\begin{tabular}{lcc}
\hline & $\begin{array}{c}\text { Outside } \\
\text { "Normal" } \\
\text { "Normal" } \\
\text { Counseling } \\
\text { Hours }\end{array}$ \\
\hline Minimum Hours & 6.0 & 0.0 \\
Maximum Hours & 45.0 & 8.0 \\
Mean Hours & 35.6 & 2.4 \\
Standard Deviation & 8.6 & 2.3 \\
\hline
\end{tabular}




\section{Means of Communication}

Financial aid offices can offer students a number of different communication methods in order to contact the office and for the financial aid office to communicate with students. Methods include in-person, phone, mail, email, online portal, and social media (Facebook, Twitter, etc.) and email newsletters. Twenty-five colleges in the study offered students at least three different means of communication with the office, the most often offered being in-person, mail and phone. Additionally, many colleges in the study offered email as an option. Only six colleges in the study offered four different methods or more. Eleven colleges in the study only advertised two methods of communication with the office, primarily via in-person or phone.

One response that busy student services offices, like financial aid offices, have utilized to react to increased workloads and student to staff ratios is to develop frequently asked questions (FAQs). These types of self-service sources of information service students in order to allow them to find the answer to their question in a concise and easily accessible source. Figure 19 shows the number of FAQs a financial aid office had on their financial aid website. Institutions without an FAQ are listed as zeros on the chart below. 


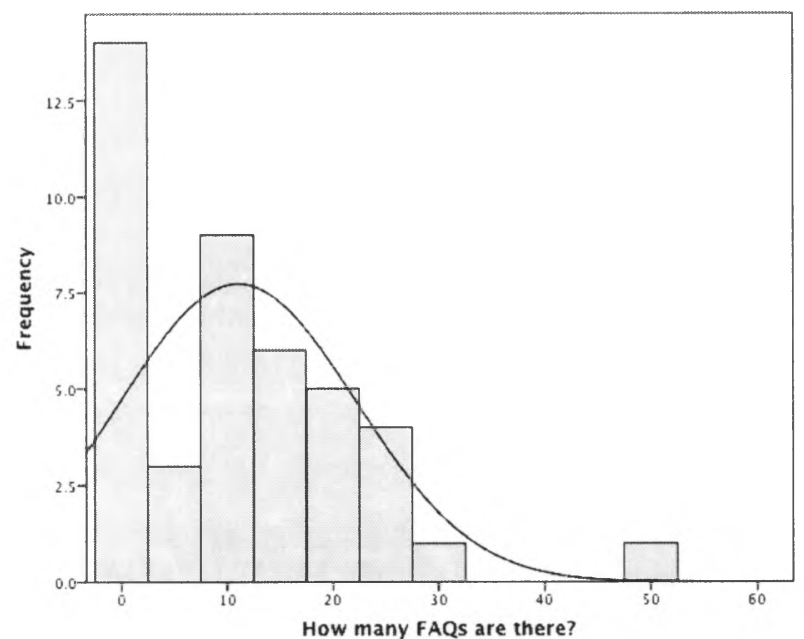

Figure 19. Count of institutions by number of FAQs on the financial aid office website.

Fourteen of the colleges in the study did not have a FAQ for students. Of the remaining colleges that provided FAQs, the mean number of FAQs was 16 with a standard deviation of 9.7. The large standard deviation reflects the long tail of the distribution and one college that had over 50 FAQs.

\section{Access to and Ease of Use of Forms}

The financial aid application process often involves financial aid forms. Offices have been moving to provide more access to financial aid forms and to make them easier to fill out for students. The first step was to provide access to the most important forms, verification forms, change of circumstances petitions, Satisfactory Academic Progress appeals, and BOG Fee Waivers in the form of either Microsoft Word or PDF documents. The next step has been to make these forms "fillable" either through "fillable" PDF documents or online "eforms" that allow complete electronic submission 
of the form from the student to the financial aid office. Figure 20 shows the frequency count of institutions of the total financial aid forms and their accessibility on their financial aid office website.

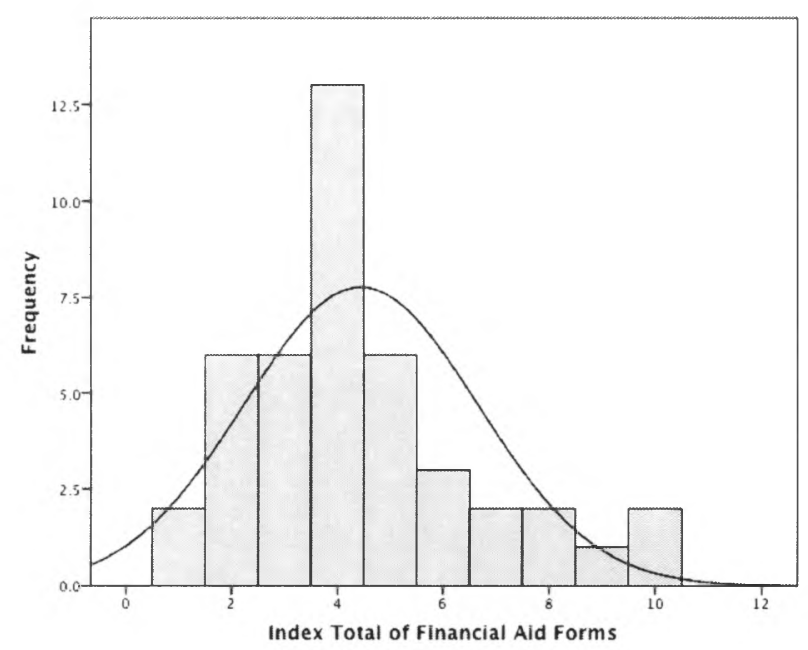

Figure 20. Count of institutions by index of total financial aid forms on the financial aid office website.

The support of languages other than English could increase the access to financial aid offices for many of the California Community Colleges for both students and their families. Spanish is one of the few languages that is supported in the 43 colleges in the study. Most often, Spanish was only supported as part of the application process for the BOG fee waiver. Twenty-eight colleges in the study did not present any direct support for other languages outside of English. Fifteen of the colleges in the study provided support for at least one other language outside of English and most of the provided support for Spanish. Most often this was through the BOG fee waiver information and application. One college in the study used the inventive idea of having 
links on their financial aid website to translate the page using Google Translate. The researcher was not well trained enough to validate the usefulness of a computer translation in the area of financial aid guidance and policy.

\section{Selection for Verification}

When a student is selected for verification, the financial aid office uses a number of ways that the office can notify a student of their selection to verify information and the required next steps. The forms of notification could be sent via mail, email, online portal or the student needs to contact the financial aid office. Some of the financial aid offices in the study detailed this process and some did not. Figure 21 shows the frequency counts of institutions by the number of communication channels that the financial aid office of selection for verification could notify a student. Institutions indicated with a zero did not provide this information to students. 


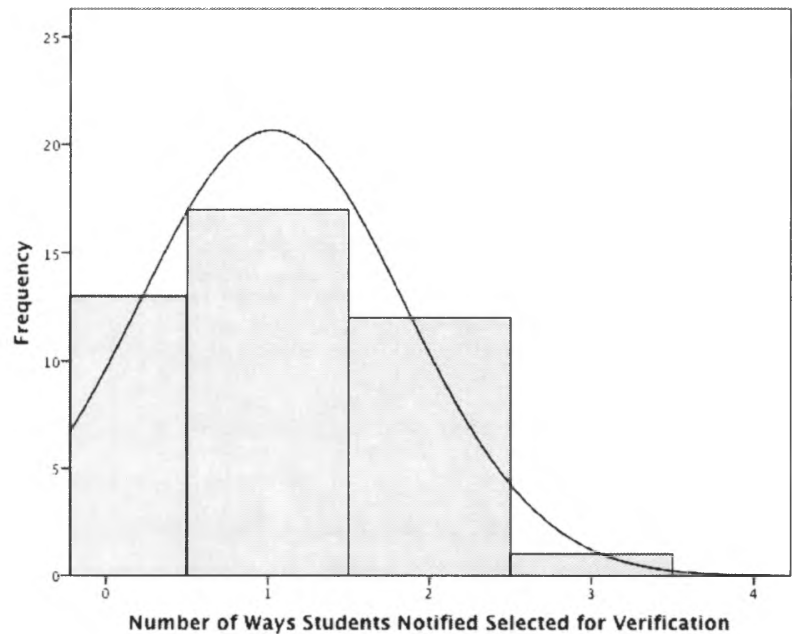

Figure 21. Count of institutions by how students are notified of being selected for verification.

The largest number of colleges (17) only specified one method that students were notified that they were selected for verification and the next steps that the student needed to complete. The colleges that only used one method usually used an email to the student or a mailed letter or post card to notify the student of their selection for the verification process. Thirteen colleges never specified to students how they would be notified if they were selected for verification. The remaining number of colleges used at least two methods or more to notify students.

In addition to students being notified of verification, student usually are required to then turn in documents and forms in order to complete the verification process. Some financial aid offices were detailed in the different options students had to turn in the verification documents and forms, while other financial aid offices did not provide any forms or describe the process at all. Figure 22 shows the frequency count of institutions 
based on the options that they provided to student in order to submit verification documents and forms.

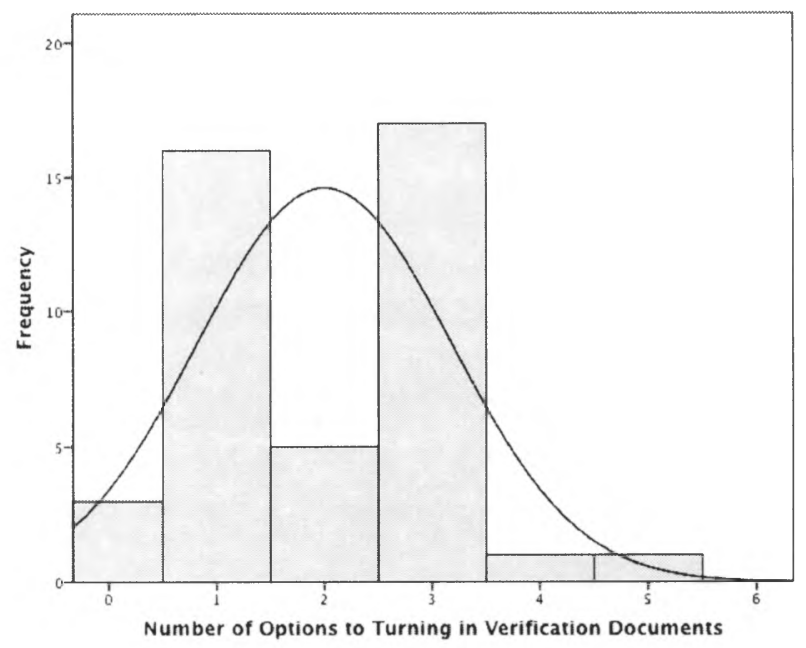

Figure 22. Count of institutions by how students can submit verification documents.

A large number of colleges, 16 colleges only provided one method one officially stated method of turning financial aid documents into the office. Many of these colleges that only provided one method instructed students to mail in documents or in a few cases, bring the documents to the financial aid office in person. The other largest group of colleges, 17, provided multiple methods to submit documents to the office, included mailing, faxing, or in-person. One college in the study had moved to online eforms that allowed their students to electronically sign on the college's website and fill out, sign and electronically submit their forms. The college even allowed the student to attach PDFs or other image files to be electronically submitted. 
Award Letters

Finally, some of the institutions provided timelines for students of when they should expect to receive a financial aid award letter. Most financial aid offices in the study did not provide a timeline. For those institutions that did provide a timeline, it ranged from four to twelve weeks. Figure 23 shows the frequency count of institutions based on the timeline provided to students. Institutions with a zero did not provide a timeline to students.

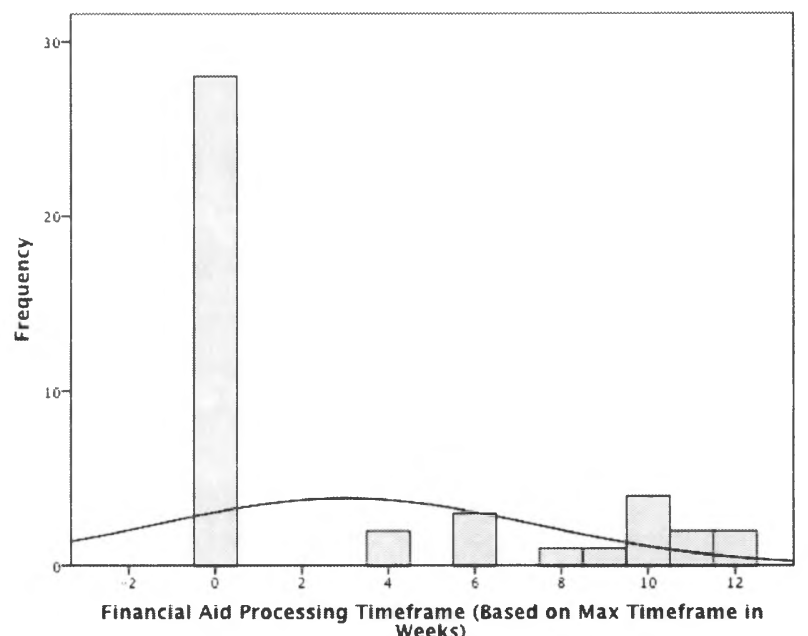

Figure 23. Count of institutions by timeframe given to students in weeks to process application.

Of the schools in the study only 15 provided a timeline for students of how long it would take to be processed. The overwhelming majority, 28 colleges, did not provide any timeline to students about how long it would take to process their application. Over the colleges that did prove a timeline, the mean was 8.6 weeks, or slightly over two months. The standard deviation was 2.7 weeks. The largest grouping of colleges, 4 
colleges, reported 10 weeks, or two and half months.

The Findings II - Factors to Failure Rates

Multiple-regression analysis was run for both the first method used to calculate the institutional application failure rate and the second method used to calculate the institutional application failure rate and for each ethnic group, resulting in ten multipleregression models. For the first failure rate (students who did not complete the application process but still enrolled), it was run for African-American students, Asian students, Hispanic students, white students and all student groups combined. Table 6 shows the results from the first five models. The table shows the standardized beta coefficient for each independent variable and is presented side-by-side for student ethnicities and the four groups combined for ease of comparison. Standardized coefficient betas are indicated with their level of significance. 
Table 6.

Institutional application failure rates that still enrolled by ethnicity and all students.

Failure Rates for each Ethnic Groups and Overall Students

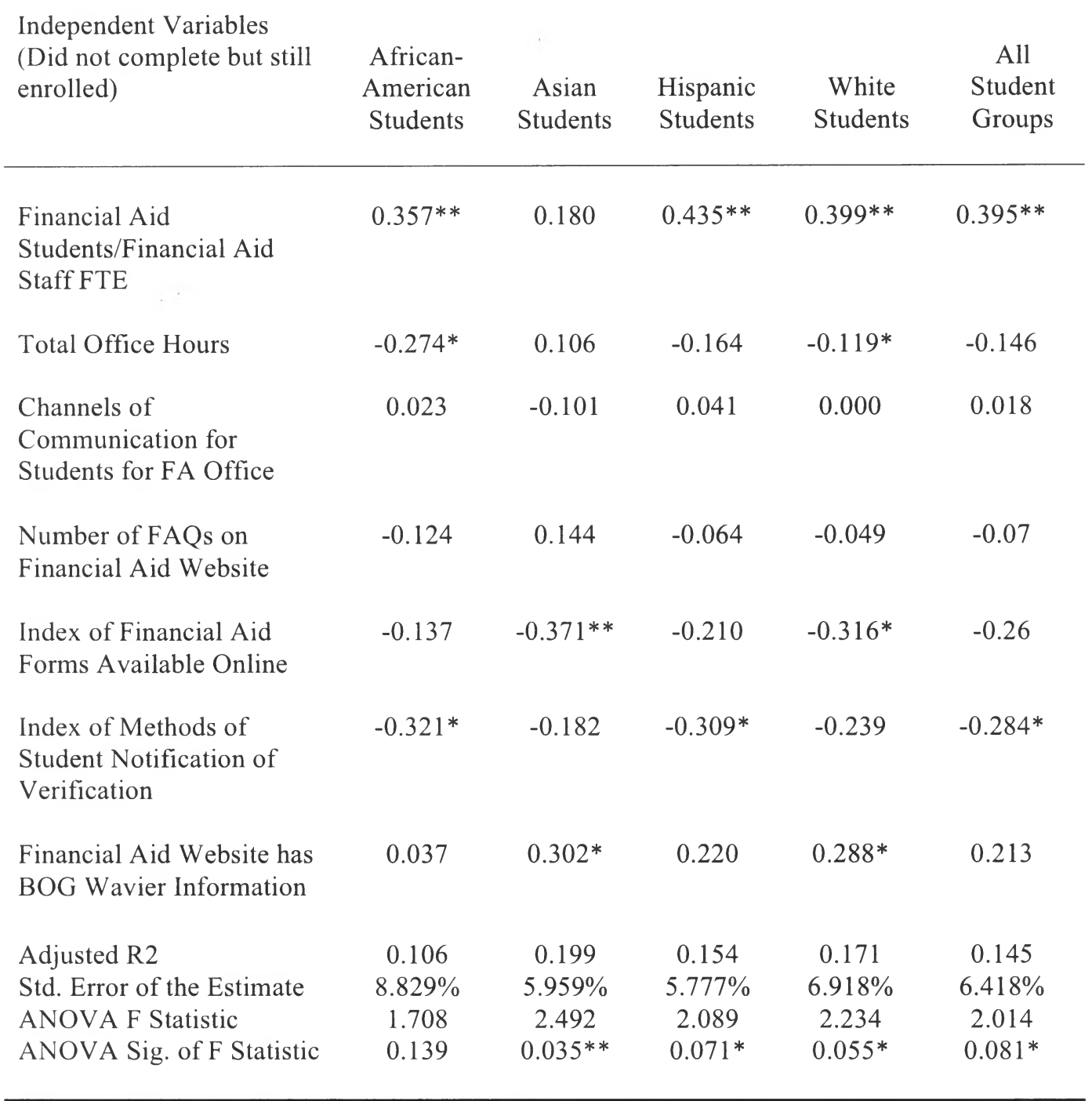

Note: ${ }^{*} p<.1 .,{ }^{* *} p<.05 .,{ }^{* * *} p<.01$. 
Based on the first calculated failure rate, the ratio financial aid students to financial aid staff FTE for African-American, Hispanic, White Student, and all student groups showed increases in failure rate the higher the ratio with significance at either $p$ $<.05$ or $\mathrm{p}<.01$. Total office hours had a weak level of significance $(\mathrm{p}<.1)$ in reducing failure rates for African-American and White students. Availability of financial aid forms online had significance $(\mathrm{p}<.05)$ for Asian students and weak significance $(\mathrm{p}<$ .1) for White students at reducing failure rates. Increased methods of notification of verification had weak significance $(\mathrm{p}<.1)$ for African-American, Hispanic and all students groups at reducing failure rates. Finally, information about the BOG fee waiver on the financial aid website had weak significance $(\mathrm{p}<.1)$ for Asian and White students at increasing application failure rates.

Table 7 shows the results from the second five models using the overall failure rate for the institutional application process. The table shows the standardized beta coefficient for each independent variable and is presented side-by-side with all of the student ethnicities and the four groups combined for comparison. Betas are indicated with their level of significance. 
Table 7.

Institutional overall application failure rates by ethnicity and all students.

Failure Rates for each Ethnic Groups and Overall Students

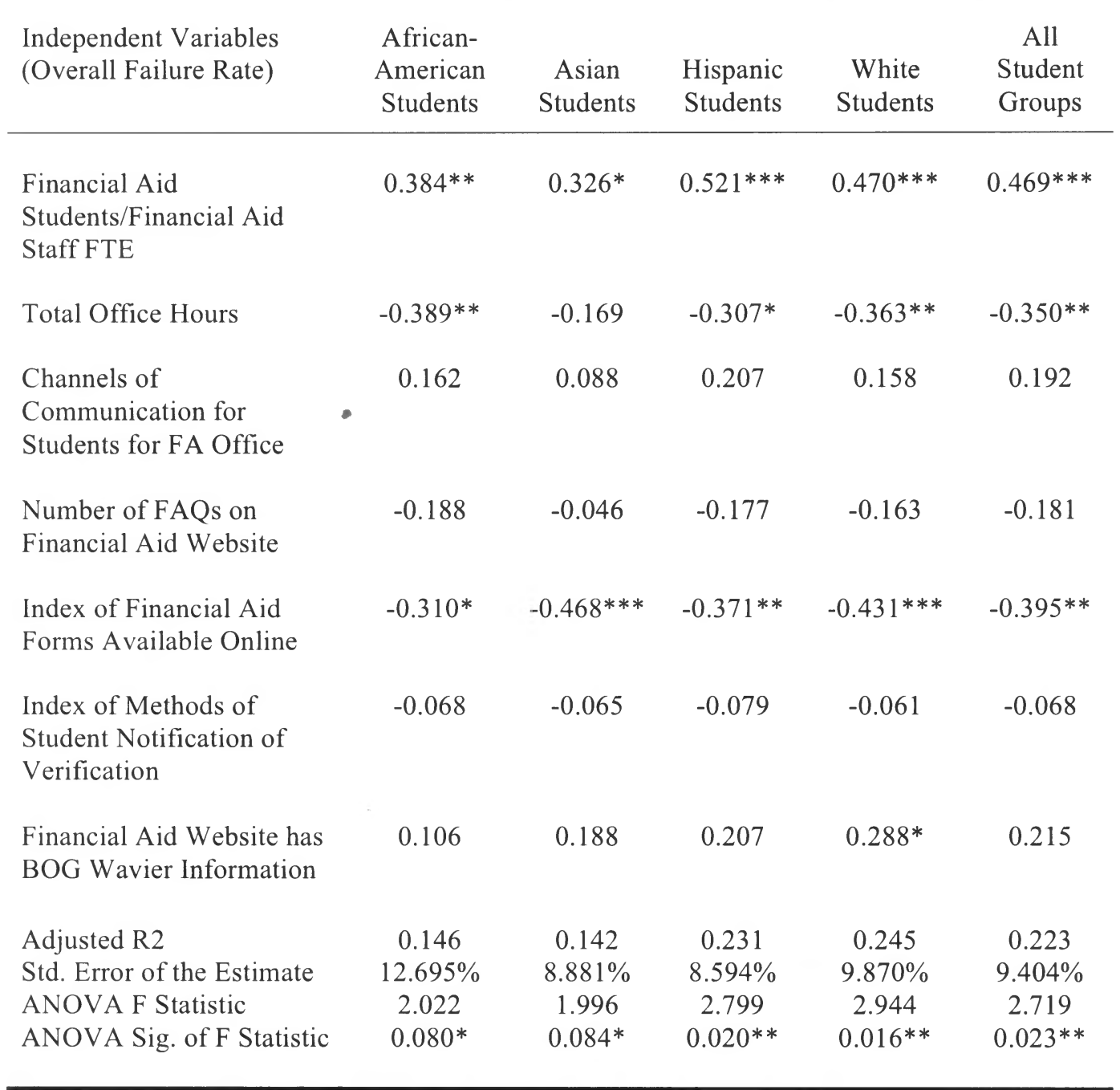

Note: ${ }^{*} p<.1,{ }^{* *} p<.05,{ }^{* * *} p<.01$.

Based on the second calculated failure rate the ratio financial aid students to financial aid staff FTE for African-American $(\mathrm{p}<.05)$, Asian $(\mathrm{p}<.1)$, Hispanic $(\mathrm{p}<.01)$, White 
Student $(\mathrm{p}<.01)$, and all student groups $(\mathrm{p} .<.01)$ showed increases in failure rate the higher the ratio. Total office hours showed increased levels of significance $(p<.05)$ in reducing failure rates for African-American, White and all student groups, while Hispanic students had a weak level of significance ( $\mathrm{p} .<.1)$. Availability of financial aid forms online had significance (at either $\mathrm{p}<.05$ or $\mathrm{p}<.01$ ) for Asian, Hispanic and White students, as well as all student groups. Additional availability of financial aid forms online had weak significance $(\mathrm{p}<.1)$ for African-American students at reducing failure rates. Increased methods of notification of verification had no significance for any student ethnicity groups for this failure rate. Finally, information about the BOG fee waiver on the financial aid website still had weak significance $(p<.1)$ White students at increasing application failure rates.

\section{Summary and Synthesis}

The descriptive statistics show the wide variance within the study of the institutional financial aid application process that currently exists at the California Community Colleges. A student who might apply for financial aid from one college in the study might have a very different experience of the institutional application process then the same student at a different college in the study a few miles away. The statistical analysis reveals a number of positive and negative correlations with statistical significance between the aspects of the institutional application process and the institutional failure rate. There are commonalities between some of the student ethnicity 
groups as well as some divergent paths. These findings and their implications are fully explored in the Chapter 5. 
Chapter Five: Discussion and Recommendations

Overview

The study reviewed and quantified the institutional financial aid process at 43

California Community Colleges that students completed in order to receive financial aid and enroll in classes. The study used statewide data from the California Community College Chancellor's Office DataMart to statistically analyze the components of the institutional financial aid processes and a college's failure rates for students who did not successfully complete the process. Two types of failure rates were calculated and used in the analysis for both the overall student population who completed a FAFSA, broken down by student ethnicity for African-American, Asian, Hispanic and White students.

The study was guided by two research questions. The first research question was:

R1: How does the process of the community colleges' institutional financial aid application influence students' completion of the process?

Additionally, the sub-research question for the dissertation is:

R2: How does the process of the community colleges' institutional financial aid application influence African-American, Asian, Hispanic, and White students' completion of the process?

The hypotheses for R1 is that aspects of the institutional financial aid application process that increase available information about financial aid programs to students, increase the amount of communication to students about their application status, 
increase the methods and amounts of contact for students to the financial aid office, and increase the simplification of the process resulting in higher completion rates of the process. The hypothesis for $\mathrm{R} 2$ is that the aspects of the institutional financial aid process will similarly affect different racial groups. 
Table 8.

Summary Comparing Results Across Groups and Two Failure Rate Measures

Failure Rates for each Ethnic Groups and Overall Students

\begin{tabular}{|c|c|c|c|c|c|}
\hline \multirow[t]{2}{*}{$\begin{array}{l}\text { Independent Variables } \\
\text { (Did not complete but } \\
\text { still enrolled) }\end{array}$} & $\begin{array}{l}\text { African- } \\
\text { American } \\
\text { Students }\end{array}$ & $\begin{array}{l}\text { Asian } \\
\text { Students }\end{array}$ & $\begin{array}{l}\text { Hispanic } \\
\text { Students }\end{array}$ & $\begin{array}{l}\text { White } \\
\text { Students }\end{array}$ & $\begin{array}{c}\text { All } \\
\text { Student } \\
\text { Groups } \\
\end{array}$ \\
\hline & FR1 FR2 & FR1 FR2 & FR1 FR2 & FR1 FR2 & FR1 FR2 \\
\hline $\begin{array}{l}\text { Financial Aid } \\
\text { Students/Financial Aid } \\
\text { Staff FTE }\end{array}$ & $+* * \quad+*$ & $+* *$ & $\begin{array}{c}+* *+* * \\
*\end{array}$ & $+* *+* * *$ & $+* *+* * *$ \\
\hline Total Office Hours & -* $\quad-* *$ & & $-*$ & $-* \quad-* *$ & $-* *$ \\
\hline $\begin{array}{l}\text { Channels of } \\
\text { Communication for } \\
\text { Students for FA Office }\end{array}$ & $-*$ & & & $-*$ & \\
\hline $\begin{array}{l}\text { Number of FAQs on } \\
\text { Financial Aid Website }\end{array}$ & & & & & \\
\hline $\begin{array}{l}\text { Index of Financial Aid } \\
\text { Forms Available } \\
\text { Online }\end{array}$ & $-*$ & $-* * \ldots * * *$ & $-* *$ & $-* \quad-* * *$ & $-* *$ \\
\hline $\begin{array}{l}\text { Index of Methods of } \\
\text { Student Notification of } \\
\text { Verification }\end{array}$ & $-*$ & & $-*$ & & $-*$ \\
\hline $\begin{array}{l}\text { Financial Aid Website } \\
\text { has BOG Wavier } \\
\text { Information }\end{array}$ & & $+*$ & & $+* \quad+*$ & \\
\hline Adjusted R2 & $.11 \quad .15$ & .20 .14 & $.15 \quad .23$ & $.17 \quad .25$ & $.15 \quad .22$ \\
\hline $\begin{array}{l}\text { Std. Error of the } \\
\text { Estimate }\end{array}$ & $\begin{array}{c}8.8 \% 12.7 \\
\%\end{array}$ & $\begin{array}{cc}6.0 & 8.9 \\
\% & \%\end{array}$ & $\begin{array}{cc}5.8 & 8.6 \\
\% & \%\end{array}$ & $6.9 \% 9.9 \%$ & $6.4 \% 9.4 \%$ \\
\hline
\end{tabular}


The findings from the study indicate for $\mathrm{R} 1$, for the first institutional failure rate, the ratio of financial aid students to FTE financial aid staff increases failure rates while the more methods that a financial aid office used to notify students they were selected for verification decreased failure rates. Both of these correlations had significance (see Table 6 in Chapter 4 for full details). For the second institutional failure rate, the ratio of financial aid students to FTE financial aid staff increased failure rates. Additionally, for the second institutional failure rate, the higher total number of financial aid office hours and increased access to financial aid forms decreased the failure rate. All three of these correlations were with significance (see Table 7 in Chapter 4 for full details).

The findings from the study indicate for $\mathrm{R} 2$, for the first institutional failure rate, for African-American, Hispanic and White students, financial aid student to staff FTE ratio increased failure rates similar to the overall student population. Higher total office hours decreased failure rates for African-American and White students based on the first institutional failure rate. Increases in access to the financial aid forms decreased failure rates for Asian and White students. More methods of notification to students about being selected for verification decreased failure rates for African-American and Hispanic students. Finally, information about the BOG fee waiver on the financial aid website increased failure rates for Asian and White students.

The findings from the study indicate for R2, based on the second institutional failure rate, for African-American, Asian, Hispanic and White students, financial aid 
student to staff FTE ratio increased failure rates. Higher total office hours decreased failure rates for African-American, Hispanic and White students. Increased access to financial aid forms decreased failure rates for Asian, Hispanic and White students. Finally, based on the second institutional failure rate, information about the BOG fee waiver on the financial aid website increased failure rates.

The rest of this chapter covers interpretations of the findings from Chapter 4, the limitations of the findings, the implications of these findings for educational leadership in financial aid, educational equity for students, policy issues for financial aid, and methodological advancement for financial aid researchers and administrators. The chapter concludes with recommendations for further study and final conclusions.

\section{Interpretation of Findings}

Based on the literature review discussed in Chapter 2 and the formal and informal discussions within the financial aid administrator community at conferences, many of these findings reflect the intuitive feeling of many who work in financial aid. The statistically significant findings from Chapter 4 on financial aid students to staff FTE ration, higher total office hours, financial aid forms, methods of notification to students of verification, and BOG fee waiver information are discussed below in the context of the overall student population and specific ethnicities. 


\section{Financial Aid Students to Staff FTE Ratio}

This first finding for both overall student population and individual student ethnicities found the higher the ratio of financial aid students to financial aid staff (based on office FTE) correlates with significance to higher failure rates. Logically, this would seem to make sense. The higher number of students to each financial aid staff meeting would mean that there is less time and attention that each staff member could provide to any given student. While technology and economies of scale can help a financial aid office balance the repetitive tasks of financial aid and possibly counter act the larger student to staff ratios, high student to staff ratio might also indicate the priorities of a college in its investment in the financial aid office.

The colleges in the study ranged in ratios from around 250 students per staff member to 2750 . This is a ten-factor increase difference between the smallest and largest college ratios. The largest grouping of colleges for student to staff ratios was between 750 and 1000 students per staff member. In real terms, a staff member who works 40 hours per week, with two weeks a year for vacation, works 2,000 hours a year. In minutes, a staff member works 120,000 minutes a year assuming no breaks or sick time off. At the low staff ratio end of 250 students, each staff member could theoretically put 480 minutes, or 8 hours, of time towards each student, each school year. At the high end of the staff ratio of 2750 students, each staff member could only theoretically put 43 minutes, or three-quarters of an hour, of time towards each student, 
each school year. This assumes that all financial aid staff sees students or have a direct connection to helping students complete and receive financial aid.

Budget cuts, staff reductions, furlough days, and large increases in students applying for financial have most likely driven the student to staff ratio even higher since the 2009-2010 school year when this data was collected for the study. Based on the study, student to staff ratio impacts the overall student failure rate and all student ethnic group failure rates with the exception of Asian students (based on the first calculated failure rate).

Higher Total Office Hours

Closely linked to the above financial aid students to staff ratio, the total number of office hours had significant impact when using the second calculated failure rate for all student groups and African-American, Hispanic, and White students. Using the first calculated failure rate, African-American and White students also showed significant impact on the failure rate. Again, this finding based on the literature and general consensus of the financial aid community, does not come as a large surprise. Increasing the number of hours that students might be able to access the financial aid, based on the study, reduces the student failure rates in completing the institutional financial aid process.

Budget cuts, staff reductions, furlough days, and large increases in students applying for financial have driven financial aid offices to reduce or struggle to maintain 
their office hours. Of the colleges in the study, most maintained standard business hours on Mondays through Thursdays. Some colleges in the study had office hours to open a little early and stayed open late a few nights a week. Among most colleges in the study, the financial aid office was only open a half day on Fridays. A number of colleges in the study also reduced their open office hours during peak application processing times in order to allow staff to focus on the processing of student financial aid files. None of the colleges in the study had office hours on the weekends, even when some community colleges in the study had scheduled classes on the weekend.

Open office hours represent an access issue for students to contact the financial aid office and ask questions when they run into roadblocks in the process. Based on the study, reducing office hours has a direct negative impact on students completing the process.

\section{Financial Aid Forms}

In the study, based on the first calculated failure rate, Asian and White students had a decrease in application failure rates when there was an increase in access to the financial aid forms. For the second calculated failure rate, not only did Asian and White students have a decrease in application failure rates, but Hispanic and the overall student population did as well. The colleges in the study ranged from not having any of their financial aid forms online for their students, to having them online, but maybe still 
as a Microsoft office document, to having a fillable PDF, to having a fully online form which students could sign and submit electronically.

Additionally, some colleges only provided a small portion of their forms online and required students to come to the financial aid office for additional forms. Often the forms that required students to come to the financial aid office included financial aid petitions and dependency override reviews. The findings from the study suggest that by increasing the availability of forms and the ease through which students can fill out the forms, the application failure rates declines for both the overall student group (based on the second calculated failure rate) and many of the student ethnic groups.

Access to and availability of financial aid forms is an easy fix for most financial aid offices. A little extra effort is required to update websites and make PDF forms fillable to allow students with computer access to type in their information. Fillable forms also reduce errors due to illegible writing and can also be structured to further reduce student error by requiring certain form items and validating date fields. Methods of Notification to Students of Verification

The methods used by a college to notify students of being selected for verification had a small level of significance $(p<.1)$ based the first calculated failure rate for the overall student group as well as African-American and Hispanic students. Increased methods of notification decreased the application failure rate. Significance disappears completely for the second calculated failure rate for the overall group and all 
student ethnic groups. The study found that using multiple communication channels to reach students about being selected for verification reduces the application failure rate, particularly for those students who end up still enrolling in the college even though they did not complete the application process. Additional refinement and study might be needed to further explore this partial finding.

BOG Fee Waiver Information

A particularly surprising finding of the study was the impact of the financial aid office presenting information about the BOG fee waiver on their financial aid website. The BOG fee waiver can be received through the traditional financial aid process of the FAFSA, but can also be a short circuit in the process if a student only wants to have their fees waived at the college. In order to qualify for the program, students still need to be low-income and complete an alternative form to the FAFSA. Asian and White students, based on the first calculated application failure rate, showed significant increased application failure rates significant $(p<.1)$ when BOG fee waiver information was presented on the financial aid website. White students also maintained an increased and significant application failure rate $(\mathrm{p}<.1)$, using the second calculated failure rate.

Additionally, study is needed to explore the decision making process of students who have completed a FAFSA, but then choose to complete another process in order to have their fees waved at the college in order to attend. This finding presents more questions then answers. Questions include what demographic characteristics do low- 
income students who complete the FAFSA and BOG waiver share and do not share.

One hypothesis might be that low-income students find information on the BOG waiver then give up the traditional financial aid process because they still live with their parents and only need to cover the fee cost of the college. This finding is particularly timely due to the recent conversation about the role and purpose of the BOG fee waiver (California Community Colleges Student Success Task Force, 2012).

\section{Limitations}

A limitation of this study and the findings comes from the complexity of the problem and the inability to completely isolate the many independent variables that might impact student failure rates during the financial aid application process. For example, the study design cannot account for students who simply change their mind about going to college in the middle of the process or get a job and decide not to enter the college. Many of these factors are completely independent of the financial aid process. Other studies have looked at why students do not start or do not complete parts of the financial aid process--almost exclusively about the FAFSA--and found that several factors may influence results regarding the decision not to start or complete the aid process (Kantrowitz, 2009a, 2009b; King, 2004, 2006). A financial aid office cannot be held responsible for choices of students completely out of their or the college's control. 
But many independent factors, for instance a student's background, economic status, or previous education, should not be accepted by financial aid offices as reasons for student failure to complete the process; clearly, offices can and should impact these students' participation and completion in the process. Nevertheless, the limitations of the study that focused on the institution instead of the student as the focal point might result in these additional independent variables obscuring the findings.

Additionally, the findings of this study are limited to the California Community Colleges. Many other large community college systems in the United States have similar characteristics, but in the end, the California Community Colleges remain a set of institutions unto themselves. However, the sheer diversity, variability and size of the California Community College system does suggest some level of generalizability of the findings.

A smaller limitation of the study is the student failure rates were calculated using information form the 2009-2010 school year (the most recent available at the time of this study) and the institutional factors were not collected until the Fall of 2011. This gap between reporting and collection might result in process changes that were not in place during the 2009-2010 school year. In other words, the experience of the students that reflect the calculated failure rates might not be the same as those collected in the fall of 2011. While a great deal of care was taken to limit this effect, including 
checking with a number of the community colleges in the study to see how much their process had changed, the time gap remains a limitation of the study.

\section{Implications}

The study creates a number of implications for the institutional implementation of the financial aid application process. The first implication is the role of educational leadership in financial aid. Based on the study, a number of factors impact the failure and success rates for students. Financial aid leaders need to take this into consideration when making decisions that affect the failure and success rate. The study suggests that student to staff ratios, office hours, financial aid forms, notifications of verification, and BOG waiver information significantly affects failure rates for the institutional application process. At the very least, financial aid administrators need to take these factors into consideration when complementing and deciding on changes to these aspects of the financial aid process. In a climate of decreasing resources and increasing student demand for financial aid, changes to the financial aid process need to acknowledge the impact and justify the trade offs of policy and budget choices that impact the institutional financial aid application.

Next, the study found that the institutional financial aid process affects student ethnic groups differently. The implication for educational equity is that all students, regardless of the community college they choose (or have chosen for them by proximity), deserve to have a financial aid process that meets their needs. The colleges 
in the study had fairly consistent overall failure rates based on both the first calculated and second calculated failure rates across their own student ethnic groups, but large gaps are evident in the failure rates between the colleges. Equity for students requires, at the very least, an even playing field exist for students across the California Community Colleges. Based on this study, equity does not currently exist in the student experience of the financial aid process across the California Community College.

Financial aid policy comes from the federal, state and institutional levels. This study indicates even with the vast majority of federal and state financial aid regulations being consistent across the colleges of the study, the implementation of the regulations is anything but consistent. While inconsistency could certainly be used to meet student needs and the needs of a community, many of the colleges in the study are not using student success through the process as the driver for regulation implementation, based only on the significantly high failure rates at certain colleges. An implication of this study is that federal, state and institutional financial aid policies should focus on meeting the needs of the student and communities these colleges serve. The current financial aid process, as discussed earlier in Chapter 2, is a process that is focused on meeting the needs on the supply-side instead of meeting the needs on the demand-side. In this case, the supply-side is the source of the funds (federal and state governments) and colleges, instead of the demand-side — the students and communities. 
Finally, this study developed a tool for collecting quantifiable data across colleges of the institutional financial aid process. The implication of this study to methodological advancement is that very complex processes with nearly unlimited number of independent variables can be modeled, data collected based on that model, and analyzed. Second to this, the framework and modeling can easily be adopted by financial aid administrators for analyzing their own financial aid process and compare benchmarks to other colleges. The implication for this study is that it will lay a foundation for further research by giving the tools to the financial aid administrators to know the impact of their financial aid processes.

\section{Recommendations for Action}

The first recommendation for action is that all community college financial aid offices need to review their critical path and feedback loops to understand how these processes might impact student success through the process. The questions that must be asked by financial aid administrators is, why is this process designed this way? Is the process geared toward student success through the process or, is it geared toward organizational and administrative ease? If the answer is organizational ease, then the question is, at what cost can the process be eased toward student success? Tied closely with this call to action, financial aid offices should look to the easy-implemented changes that could improve student success rates through the application process. There still appears to be a great deal of "low hanging fruit" that could be addressed quickly to 
improve the process for students and reduce failure rates. One particular point was the importance of increased access and inclusion of as many financial aid forms as possible on the financial aid website. To not include these forms at this point in time, begs the question of the motivation and stance on student access by a financial aid office that chooses not to take these simple steps.

The second recommendation for this study is that budget and policy decisions on the operations of the financial aid office need to take into consideration what impact those decisions have on student experience and success throughout the process. Budget and policy decisions need to be student focused, and student voice and experience need to be front and center in these conversations. A very simple way to determine a college's priorities is to look at their budget and resource allocation. Resources and staff are scarce at the California Community Colleges, but the choice to cut resources and staff in the financial aid office speaks about priorities. Colleges need to be honest about the process, the reasons, and the impacts this will have on students.

Ultimately, the call to action to change the financial aid process needs to come from the financial aid administrators. Regardless of the budget climate or the increasing demands of regulations from the federal and state levels, there will never be enough people, time, or resources to meet all the demands of the financial aid offices at the California Community Colleges. The call to action for this study to the financial aid administrators, colleges, and policy makers is what are the priorities and how are we 
going to achieve these goals? This study shows that the institutional financial aid process impacts student success through the application process and the call to action is that administrators and policy makers need to decide on their priorities. Lack of action is still a choice and speaks volumes about choice and priorities.

\section{Recommendations for Further Study}

Additional study is needed in order to further understand the relationship between the institutional financial aid application process and students success through that process. Particularly, additional research is needed in order to refine the extraneous factors that might impact the success and failure rates. This study developed the area of the impact of institutional implementation of the financial aid process upon student success and failure through that process, but additional factors outside the scope of this study may have additional influence on student decision-making. Framing to students in the area of student services often can influence students' behavior and reactions to a process. Further study is needed to help explain and understand the student experience through the financial aid process.

Another area that needs further study is why certain student ethnic groups are impacted differently by changes in institutional application process. The scope of this study did not allow for the development of understanding of what aspects of the institutional financial aid process might help explain why different student ethnic groups are affected at different rates by the institutional application process. 
Additionally, financial aid processes have positive affects on certain groups of students and other groups of students were negatively affected. This should not suggest that further study should be taken to understand why student ethnic groups are affected differently but the purpose of further research should not focus on explaining why those groups of students "do not get" the financial aid process. This study recommends that different student groups, based on ethnicity or other characteristics, might need different approaches to meet the needs of a student community. Further study is needed to understand these needs and provide recommendations for how to meet these needs.

Finally, further study is needed to understand why financial aid offices and colleges decided to implement their financial aid process in a particular manner. Previous studies using interviews of financial aid administrators, discussed in Chapter 2 , found that financial processes are driven by federal and state regulations. While significant regulations are imposed upon colleges by federal and state financial aid sources, also discussed in Chapter 2, a great deal of latitude is allowed and shown in the implementation by community colleges from this study. Additionally, this study suggests that administrators in the implementation have choices. Further study is needed to understand if the choice is intentional or unintentional and to understand the framework used to make these choices. This study has developed a framework for understanding the impact of the financial aid process at the institutional level, and now it needs to be expanded in depth and breadth to fully develop the picture. 


\section{Conclusion}

The institutional financial aid application process at the California Community Colleges impacts student success and failure through that process. Financial aid administrators, colleges and financial aid policy makers at all levels need to review how those processes impact student success, particularly at the institutional level. Decisions need to be made to level the playing field across the California Community College financial aid offices to increase student equity and access in order for students to fund their educational goals.

Many of the recommendations are simple changes that can be implemented with little additional resources, while other recommendations require larger structural changes. Priority needs to be given to making decisions, knowing their impact, and justifying the decisions. If the decision is made not to make changes, the reasons and the cost of those decisions need to be transparent to students and the communities the colleges serve. 


\section{References}

Apple, M. W. (2004). Ideology and curriculum (3rd ed.). Routledge.

Asher, L. (2007). Going to the source: A practical way to simplify the FAFSA. Oakland, CA: The Institute for College Access \& Success.

Baker, J., Bergeron, D., \& Madzelan, D. (2011, December). Federal Update. Presented at the Federal Student Aid Conference, Las Vegas, NV. Retrieved from http://www.ifap.ed.gov/presentations/2011FSAConference.html

Baum, S., McPherson, M., \& Steele, P. (2008). The Effectiveness of Student Aid Policies: What the Research Tells Us (p. 226). New York, NY: College Board. Retrieved from http://knowledgecenter.completionbydesign.org/resource/112

California Community Colleges Chancellor's Office. (2010). Student Financial Aid Programs. Sacramento, CA. Retrieved from http://www.ccco.edu/Portals/4/Reports/FinancialAid2010toPrint4.pdf

California Community Colleges Chancellor's Office. (2011a). Focus On Results: Accountability Reporting for the California Community Colleges. Retrieved from http://californiacommunitycolleges.cccco.edu/Portals/0/reportsTB/March_ARC C_2011.pdf

California Community Colleges Chancellor's Office. (2011b). Student Financial Aid Report. Sacramento, CA. Retrieved from 
http://californiacommunitycolleges.cccco.edu/Portals/0/reportsTB/REPORT_Fin ancial_Aid_010312_FINAL.pdf

California Community Colleges Student Success Task Force. (2012). Advancing Student Success in the California Community Colleges (p. 77).

Chen, R. (2008). Financial aid and student dropout in higher education: A heterogeneous research approach. Higher Education, 209-239.

College Board. (2011). Trends in College Pricing 2011 (p. 31). Retrieved from http://trends.collegeboard.org/college_pricing/

Cunningham, A. F., \& Kienzl, G. S. (2011). Delinquency: The Untold Story of Student Loan Borrowing. Washington, DC: Institute for Higher Education Policy. Retrieved from http://www.ihep.org/assets/files/publications/a-f/DelinquencyThe_Untold_Story_FINAL_March_2011.pdf

Davis, J. S. (Ed.). (1997). Student Aid Research. A Manual for Financial Aid Administrators. Washington, DC: National Association of Student Financial Aid Administrators.

DesJardins, Stephen L, \& McCall, B. P. (2010). Simulating the Effects of Financial Aid Packages on College Student Stopout, Reenrollment Spells, and Graduation Chances. Review of Higher Education, 33(4), 23. 
DesJardins, Stephen L, Ahlberg, D. A., \& McCall, B. P. (2006). An Integrated Model of Application, Admission, Enrollment, and Financial Aid. The Journal of Higher Education, 77(3), 381.

FAFSA - Free Application for Federal Student Aid. (n.d.). Retrieved October 8, 2009, from http://www.fafsa.ed.gov/faq003.htm

Federal Student Aid - IFAP: iLibrary - Federal Student Aid Handbook. (n.d.). Retrieved November 7, 2009, from http://ifap.ed.gov/ifap/byAwardYear.jsp?type=fsahandbook\&awardyear=20092010

Financial Aid General Info: Financial Aid Info. (n.d.). Retrieved April 15, 2012, from http://www.icanaffordcollege.com/index.cfm?navid=9

Hayward, G., Jones, D., McGuinness, Jr, A., \& Timar, A. (2004). Ensuring Access with Quality to California's Community Colleges. The National Center for Public Policy and Higher Education.

Higher Education Amendments of 1992. (1992).Public Law No: 102-325.

Johnson, H., \& Reed, D. (2007). Can California Import Enough College Graduates to meet workforce needs. California Counts: Population trends and profiles, 8(4).

Kantrowitz, M. (2009a). FAFSA Completion Rates by Level and Control of Institution. Student Aid Policy Analysis. Retrieved from http://www.finaid.org/educators/20091014fafsacompletion.pdf 
Kantrowitz, M. (2009b). Analysis of why some students do not apply for financial aid. Student Aid Policy Analysis, 2, 2010.

Kantrowitz, M. (n.d.). History of Student Financial Aid. History of Student Financial Aid. Retrieved from http://www.finaid.org/educators/history.phtml

Key Facts. (2012). Retrieved April 14, 2012, from http://californiacommunitycolleges.cccco.edu/PolicyInAction/KeyFacts.aspx King, J. E. (2004). Missed Opportunities: Students Who Do Not Apply for Financial Aid. Washington, D.C.: American Council on Education, Center for Policy Analysis.

King, J. E. (2006). Missed opportunities revisited: New information on students who do not apply for financial aid. Washington, D.C.: American Council on Education, Center for Policy Analysis.

Kollock, S., Parkinson, M., \& Baker, J. (2011, December). 2012-13 FADFSA \& Verification Changes. Presented at the Federal Student Aid Conference, Las Vegas, NV. Retrieved from http://www.ifap.ed.gov/presentations/2011FSAConference.html LaManque, A. (2009). Factors Associated with Delayed Submission of the Free Application for Federal Financial Aid. Journal of Applied Research in the Community College, 17(1), 6. 
Lassila, N. E. (2011). Effects of Tuition Price, Grant Aid, and Institutional Revenue on Low-Income Student Enrollment. Journal of Student Financial Aid, 41(3), 2441.

Long, B. T., \& Riley, E. (2007). Financial Aid: A Broken Bridge to College Access? Harvard Educational Review, 77(1), 39.

MacCallum, M. (2008). Effect of Financial Aid Processing Policies on Student Enrollment, Retention and Success. NASFAA Journal of Student Financial Aid, $37(2), 17-32$.

McDavid, J. C., \& Hawthorn, L. R. L. (2006). Program evaluation \& performance measurement : an introduction to practice. Thousand Oaks: SAGE Publications. Mendoza, P., Mendez, J., \& Malcolm, Z. (2009). Financial Aid and Persistence in Community Colleges: Assessing the Effectiveness of Federal and State Financial Aid Programs in Oklahoma. Community College Review, 37(2), 112.

Moore, C., \& Shulock, N. (2006). State of Decline? Gaps in College Access and Achievement Call for Renewed Commitment to Educating California (p. 37) Sacramento, CA: Institute For Higher Education Leadership \& Policy. Moore, C., \& Shulock, N. (2010). Divided We Fail: Improving Completion and Closing Racial Gaps in California's Community Colleges. Sacramento, CA: Institute For Higher Education Leadership \& Policy. Retrieved from http://www.collegecampaign.org/index.php/download_file/view/103/91/ 
Mortenson, T. (2009). California at the edge of a Cliff Sacramento, CA: California Faculty Association.

Novak, H., \& McKinney, L. (2011). The Consequences of Leaving Money on the Table: Examining Persistence among Students Who Do Not File a FAFSA. Journal of Student Financial Aid, 41(3), 5-23.

Richardson, J. (2008). Demystifying and Deconstructing the College Application Process. The Journal of Negro Education, 77(4), 382.

Shulock, N., \& Moore, C. (2007). Rules of the Game. Sacramento, CA: Institute for Higher Education Leadership, Sacramento State University.

St. John, E. P. (1992). Workable Models for Institutional Research on the Impact of Student Financial Aid. Journal of Student Financial Aid, 22(3), 13-26.

The Institute for College Access \& Success. (2007). Green Lights \& Red Tap: Improving Access to Financial Aid at California's Community Colleges. Retrieved from www.ticas.org/files/pub/Green_Lights_Red_Tape.pdf

The Institute for College Access \& Success. (2010a). Financial Aid Facts at California Community Colleges (p. 2). Oakland, CA. Retrieved from http://ticas.org/files/pub/ccc_fact_sheet.pdf

The Institute for College Access \& Success. (2010b). After the FAFSA: How red tape can prevent eligible students from receiving financial aid. Retrieved from http://ticas.org/files/pub/AfterFAFSA.pdf 
Appendices 
Appendix A Financial Aid Institutional Process Collection Instrument

\section{Financial Aid Audit Form}

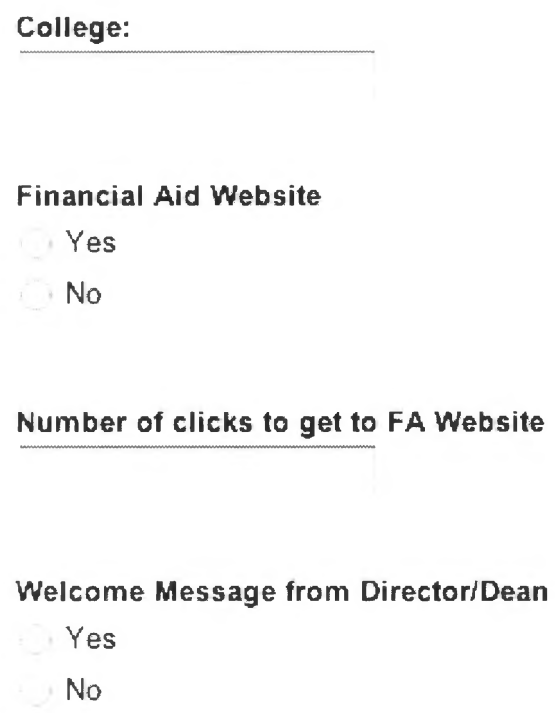


Wednesday Office Hours

Thursday Office Hours

Friday Office Hours

Saturday Office Hours

\section{Counseling Hours}

Are the counseling hours same as office hours?

Yes

No

Monday Counseling Office Hours

Tuesday Counseling Office Hours

Wednesday Counseling Office Hours 
Thursday Counseling Office Hours

Friday Counseling Office Hours

Saturday Counseling Office Hours

Sunday Counseling Office Hours

\section{Office Access For Students}

How can students contact the office?
Phone
Email Yes No Unknown
In-person
IP
Social Media ii.e. Facebook.
Email Newsletter

Is there a way for students to submit comments/suggestions?

$$
\text { Yes }
$$

No

Unknown 


\section{FA Website Resources}

Website Resources on?

$\begin{array}{ccccc}\text { Yes } & \text { Yes (links } & \text { Yes } & & \\ \text { (website } & \begin{array}{c}\text { to outside } \\ \text { page) }\end{array} \text { (PDFiword } & \text { No } & \text { Unknown } \\ \text { doc) } & & & \end{array}$

Application Process

BOG Wavier

Grants

SAP

Outside

Grants:Scholarships

Loans

Verification Process

FAO

How many FAQs are there?

Financial Aid Forms Online

Yes
Verification
SAP Petition
BOG Waillable)
fency Override
Fancial Petition


Additional Comments

\section{Multiple Language Support}

Which Other Languages are offered?

Spanish

Chinese

Vietnamese

Korean

Russian

Japanese

Other:

How are these languages supported?

Website Information

FAO Forms

PhoneiEmail Contact 


\section{General Application Process}

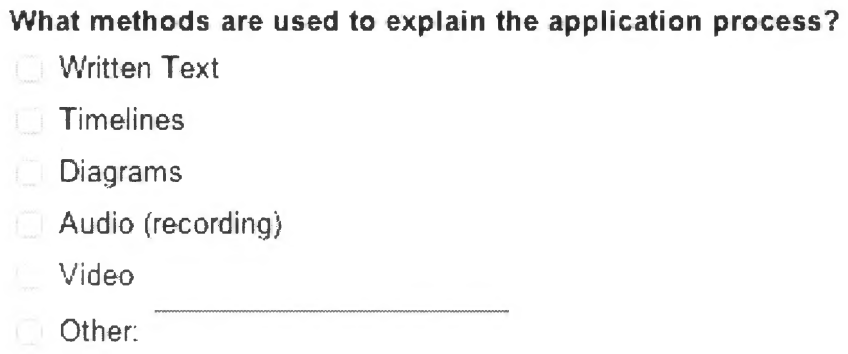

Is there an institutional application deadline (for fall semester/quarter)?

Yes

No

Not Specified

If Yes (from above), how many weeks before/after the start of fall semesteriquarter is the deadline?

use negative numbers to indicate a deadine after the start of the semesterquarter 
Additional Comments

\section{Verification Process}

How are students notified that they were selected for verification?

Letter (proactive)

Email (proactive)

Online Portali'Website (passive)

Student has to contact the office (passive)

Not indicated

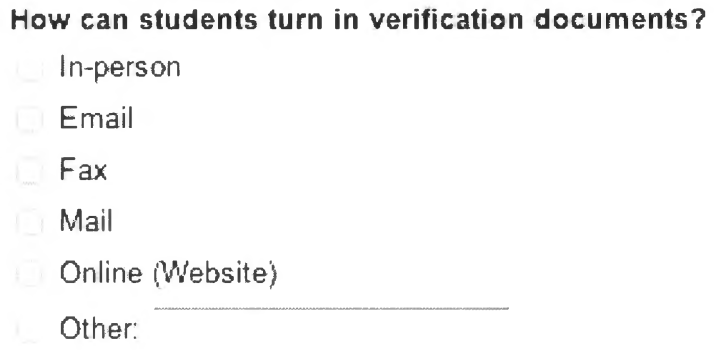

Does the school verify all students?

Yes

No 
How are students notified of verification follow up?

Students needs to check with office

Students needs to check online (website)

Email Notification

Mailed Letter

Not identified

Additional Comments about verification process

\section{Award Notification}

Are students given a timeline between applying and notification?

Yes

No

If Yes (from above), what is the timeframe?

How are students sent award notifications?

Mailed Award Letter (proactive)

Email Award Letter (proactive)

Online Award Letter (passive)

Not Specified 
Additional Comments

\section{Additional Aspects}

Types of financial aid outreach to students?

Cash for College Nights:FAFSA Completion Session

High School SessioniNights

Incentive Programs

Connect between application and enrollment

Other:

Additional Comments

Submit

Fowered by Goode Docs

Recort Abuse - Terms of Service - Additional Terms 


\section{Appendix B Quantitative Code Book}

2 Year Default Rate

- Percentage of Students who default on their student loans within two years of entering repayment

3 Year Default Rate

- Percentage of Students who default on their student loans within three years of entering repayment

Total Awarded

- Total Number of students awarded financial aid

Total with Pell

- Total number of students awarded federal Pell Grant

$\%$ with Pell Grant

- Total number of students awarded federal Pell Grant divided by Total Number of students awarded financial aid

AFRICAN-AMERICAN \% Did Not Complete File

- Percentage of students who did complete a FAFSA but did not complete the financial aid process at the school yet enrolled divided by total number of students who did complete the process and those that did not.

ASIAN \% Did Not Complete File

- Percentage of students who did complete a FAFSA but did not complete the financial aid process at the school yet enrolled divided by total number of students who did complete the process and those that did not.

HISPANIC \% Did Not Complete File 
- Percentage of students who did complete a FAFSA but did not complete the financial aid process at the school yet enrolled divided by total number of students who did complete the process and those that did not.

WHITE \% Did Not Complete File

- Percentage of students who did complete a FAFSA but did not complete the financial aid process at the school yet enrolled divided by total number of students who did complete the process and those that did not.

Total Sum of Total \% Did Not Complete File (African-America, Asian, Hispanic, White)

- Percentage of students who did complete a FAFSA but did not complete the financial aid process at the school yet enrolled divided by total number of students who did complete the process and those that did not.

Students who did not receive financial aid who completed a FAFSA

\section{AFRICAN-AMERICAN \% Did Not Complete File}

- Percentage of students who did complete a FAFSA but did not receive financial aid divided by total number of students who did complete the process and those that did not.

ASIAN \% Did Not Complete File

- Percentage of students who did complete a FAFSA but did not receive financial aid divided by total number of students who did complete the process and those that did not.

HISPANIC \% Did Not Complete File

- Percentage of students who did complete a FAFSA but did not receive financial aid divided by total number of students who did complete the process and those that did not.

WHITE \% Did Not Complete File 
- Percentage of students who did complete a FAFSA but did not receive financial aid divided by total number of students who did complete the process and those that did not.

Total Sum of Total \% Did Not Complete File

- Percentage of students who did complete a FAFSA but did not receive financial aid divided by total number of students who did complete the process and those that did not.

Institutional Variables

Staff/FA Ratio

African-American \% with Pell Grant

Asian $\%$ with Pell Grant

Hispanic \% with Pell Grant

White Non-Hispanic \% with Pell Grant

Total Sum of Headcount \% with Pell Grant

Index Of Financial Aid Website (Is there a financial aid website)

$0=$ No

$1=\mathrm{Yes}$

Number of clicks to get to FA Website (from the main college website)

Range of 1 to 3

Index Of Welcome Message from Director/Dean (Is there a welcome message from the head of the financial aid office)

$0=$ No

$1=$ Yes 
Monday Office Hours Total "Normal" (Total number of hours between 8 AM and 5 $\mathrm{PM})^{\prime}$

Range of 0 to 9

Monday Office Hours Total "Outside Normal" (Total number of hours before and after "Normal" business hours)

Range of 0 to 2.5

Tuesday Office Hours Total 'Normal'

Range of 0 to 9

Tuesday Office Hours Total 'Outside Normal'

Range of 0 to 2.5

Wednesday Office Hours Total 'Normal'

Range of 0 to 9

Wednesday Office Hours Total 'Outside Normal'

Range of 0 to 2.5

Thursday Office Hours Total 'Normal'

Range of 0 to 9

Thursday Office Hours Total 'Outside Normal'

Range of 0 to 2.5

Friday Office Hours Total 'Normal'

Range of 0 to 9

Friday Office Hours Total 'Outside Normal' 
Range of 0 to 2.5

Saturday Office Hours Total 'Outside Normal'

All equal to 0

Sunday Office Hours Total 'Outside Normal'

All equal to 0

Index of Are the counseling hours same as office hours? (Are the counseling hours of the financial aid office the same as the office hours)

$0=\mathrm{No}_{0}$

$1=$ Yes

Monday Counseling Office Hours Total 'Normal'

Range of 0 to 9

Monday Counseling Office Hours Total 'Outside Normal'

Range of 0 to 2.5

Tuesday Counseling Office Hours Total 'Normal'

Range of 0 to 9

Tuesday Counseling Office Hours Total 'Outside Normal'

Range of 0 to 2.5

Wednesday Counseling Office Hours Total 'Normal'

Range of 0 to 9

Wednesday Counseling Office Hours Total 'Outside Normal' 
Range of 0 to 2.5

Thursday Counseling Office Hours Total 'Normal'

Range of 0 to 9

Thursday Counseling Office Hours Total 'Outside Normal'

Range of 0 to 2.5

Friday Counseling Office Hours Total 'Normal'

Range of 0 to 9

Friday Counseling Office Hours Total 'Outside Normal'

Range of 0 to 2.5

Saturday Counseling Office Hours Total 'Outside Normal'

All equal to 0

Sunday Counseling Office Hours Total 'Outside Normal'

All equal to 0

How can students contact the office? [Phone] (Can students contact the financial aid via Phone)

$0=\mathrm{No}_{0}$

$1=\mathrm{Yes}$

How can students contact the office? [Email]

$0=$ No

$1=$ Yes

How can students contact the office? [In-person] 
$0=\mathrm{No}_{0}$

$1=$ Yes

How can students contact the office? [Email Newsletter]

$0=\mathrm{No}_{0}$

$1=$ Yes

How can students contact the office? [IM]

$0=$ No

$1=$ Yes

How can students contact the office? [Social Media (i.e. Facebook, Twitter)]

$0=$ No

$1=\mathrm{Yes}$

Is there a way for students to submit comments/suggestions?

$0=\mathrm{No}_{\mathrm{O}}$

$1=$ Yes

Index of Student Communications Methods (Max of 6) (Sub-score for accessibility of the financial aid office)

Range 0 to 6

Website Resources on? [Application Process] (Does the financial aid office website contain information on the Application Process)

$0=$ No

$1=$ Yes (as a link to an outside source) 
$2=$ Yes (as word or PDF document)

$3=$ Yes (as a webpage)

Website Resources on? [BOG Wavier]

$0=$ No

$1=$ Yes (as a link to an outside source)

$2=$ Yes (as word or PDF document)

$3=$ Yes (as a webpage)

Website Resources on? [Grants]

$0=\mathrm{No}_{0}$

$1=$ Yes (as a link to an outside source)

$2=$ Yes (as word or PDF document)

$3=$ Yes (as a webpage)

Website Resources on? [SAP]

$0=$ No

$1=$ Yes (as a link to an outside source)

$2=$ Yes (as word or PDF document)

$3=$ Yes (as a webpage)

Website Resources on? [Outside Grants/Scholarships]

$0=$ No

$1=$ Yes (as a link to an outside source) 
$2=$ Yes (as word or PDF document)

$3=$ Yes (as a webpage)

Website Resources on? [Loans]

$0=$ No

$1=$ Yes (as a link to an outside source)

$2=$ Yes (as word or PDF document)

$3=$ Yes (as a webpage)

Website Resources on? [Verification Process]

$0=$ No

$1=$ Yes (as a link to an outside source)

$2=$ Yes (as word or PDF document)

$3=$ Yes (as a webpage)

Website Resources on? [FAQ]

$0=$ No

$1=$ Yes (as a link to an outside source)

$2=$ Yes (as word or PDF document)

$3=$ Yes (as a webpage)

How many FAQs are there?

Range of 0 to 50

Financial Aid Forms Section 
Financial Aid Forms Online [Verification]

$0=\mathrm{No}_{0}$

$1=$ Yes (but not fillable $)$

$2=$ Yes $($ fillable $)$

Financial Aid Forms Online [SAP Petition]

$0=\mathrm{No}$

$1=$ Yes (but not fillable)

$2=$ Yes (fillable)

Financial Aid Forms Online [BOG Waiver]

$0=$ No

$1=$ Yes (but not fillable)

$2=$ Yes (fillable $)$

Financial Aid Forms Online [Dependency Override]

$0=\mathrm{No}_{0}$

$1=$ Yes (but not fillable $)$

$2=$ Yes $($ fillable $)$

Financial Aid Forms Online [Financial Petition]

$0=\mathrm{No}_{0}$

$1=$ Yes (but not fillable)

$2=$ Yes (fillable) 
Index Total of Financial Aid Forms (Max 10)

Range of 0 to 10

Which Other Languages (besides English) are offered?

Range 0 to 6

How are students notified that they were selected for verification? [Email]

$0=$ No

$1=$ Yes

How are students notified that they were selected for verification? [Online Portal]

$0=$ No

$1=$ Yes

How are students notified that they were selected for verification? [Student Has to Contact Office]

$0=$ No

$1=$ Yes

How are students notified that they were selected for verification? [Not Indicated]

$0=$ No

$1=$ Yes

Index Of how are students notified that they were selected for verification (MAX of 4)?

Range Of $0-4$

How can students turn in verification documents [In-person]? 
$0=\mathrm{No}$

$1=\mathrm{Yes}$

How can students turn in verification documents [Email]?

$0=\mathrm{No}$

$1=$ Yes

How can students turn in verification documents [Fax]?

$0=\mathrm{No}$

$1=$ Yes

How can students turn in verification documents [Mail]?

$0=$ No

$1=$ Yes

How can students turn in verification documents [Online]?

$0=\mathrm{No}_{0}$

$1=\mathrm{Yes}$

Index of Total of Turning in Verification Docs (MAX of 5)

Range of 0 to 5

Does the school verify all students?

$0=\mathrm{No}_{0}$

$1=$ Yes

How are students notified of verification follow up [Letter]? 
$0=$ No

$1=\mathrm{Yes}$

How are students notified of verification follow up [Email]?

$0=$ No

$1=$ Yes

How are students notified of verification follow up [Online/Website]?

$0=$ No

$1=$ Yes

How are students notified of verification follow up [Student needs to follow up]?

$0=$ No

$1=\mathrm{Yes}$

How are students notified of verification follow up [Not Indicated]?

$0=\mathrm{No}_{0}$

$1=\mathrm{Yes}$

Are students given a timeline between applying and notification [Total MAX of 4]?

Range of 0 to 4

Are students given a timeline between applying and notification?

$0=\mathrm{No}_{0}$

$1=$ Yes

If Yes (from above), what is the timeframe (In Max Weeks)? 
Range of 0 to 12 (in weeks)

Is there a priority deadline?

$0=\mathrm{No}_{0}$

$1=$ Yes

How are students sent award notifications? [Mailed]

$0=$ No

$1=$ Yes

How are students sent award notifications [Email]?

$0=$ No

$1=\mathrm{Yes}$

How are students sent award notifications [Online]?

$0=\mathrm{No}_{0}$

$1=$ Yes

How are students sent award notifications [Not Indicated]?

$0=\mathrm{N}_{\mathrm{O}}$

$1=\mathrm{Yes}$

How are students sent award notifications [Total Max of 3]?

$0=$ No

$1=\mathrm{Yes}$

Is there an institutional application deadline (for fall semester/quarter)? 


$$
\begin{aligned}
& 0=\text { No } \\
& 1=\text { Yes }
\end{aligned}
$$

Types of financial aid outreach to students? (Are there additional outreach that the financial aid office does, like FAFSA nights at high schools)

$$
\begin{aligned}
& 0=\text { No } \\
& 1=\text { Yes }
\end{aligned}
$$


Appendix C NIH Certificate of Completion

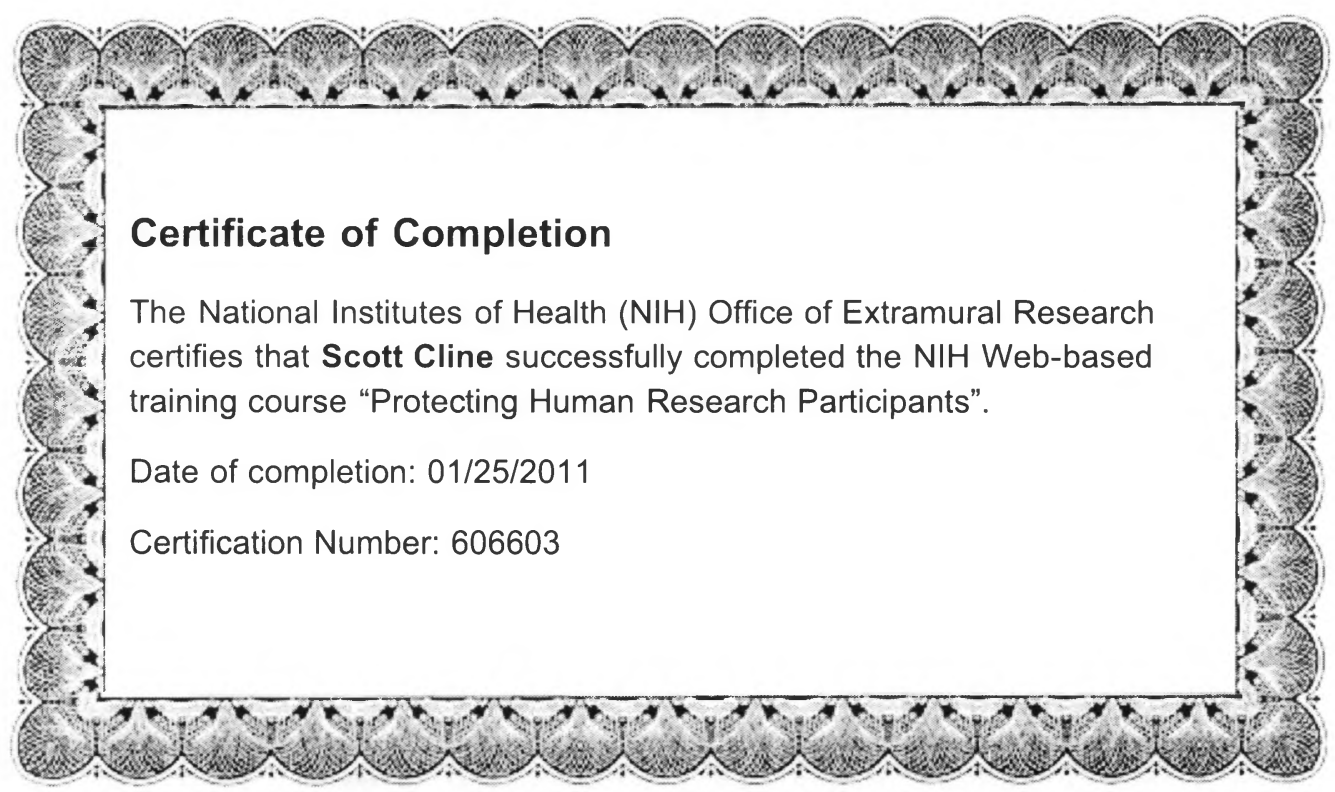




\section{Appendix D Human and Animal Protections Exemption Notice}

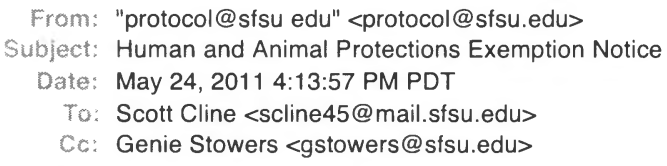

ORSP - Human and Animal Subjects has determined that your protocol, "The Impact of the Financial Aid Application Process on California Community College Students" is "Exempt" from regulatory oversight and does not need further ORSP-HAP review. Please note that your protocol will not expire, but any future changes to your research may require review.

Faculty advisors and researchers are responsible for ensuring that all publicly viewable documents are clear of grammar, spelling, readability and formatting errors.

If you change your research or have any questions, please contact us.

Regards,

Tamara Strelnik

ORSP - Human and Animal Protections

San Francisco State University

1600 Holloway Avenue

Physical Address: 469 Administration Building

Mailing Address: 250 Administration Building

Phone: 415.338.1093

Fax: 415.338.2493 ATTN: Human and Animal Protections

Email:protocol@sfsu.edu

http://research.sfsu.edu/protocol/ 